\title{
A multi-century meteo-hydrological analysis for the Adda river basin (Central Alps). Part I: Gridded monthly precipitation (1800-2016) records
}

\author{
Alice Crespi ${ }^{1} \odot$ | Michele Brunetti ${ }^{2}$ | Roberto Ranzi ${ }^{3}$ | Massimo Tomirotti ${ }^{3}$ | \\ Maurizio Maugeri ${ }^{1,2}$
}

${ }^{1}$ Department of Environmental Science and Policy, Università degli Studi di

Milano, Milan, Italy

${ }^{2}$ Institute of Atmospheric Sciences and Climate, ISAC-CNR, Bologna, Italy

${ }^{3}$ DICATAM, Università degli Studi di

Brescia, Brescia, Italy

\section{Correspondence}

Alice Crespi, Department of

Environmental Science and Policy,

Università degli Studi di Milano, Milan

20133, Italy.

Email: alice.crespi@eurac.edu

\section{Present address}

Alice Crespi, Institute for Earth Observation, Eurac Research, Bolzano, Italy

Funding information

Fondazione Cariplo

\begin{abstract}
The 1800-2016 monthly precipitation record for the upper Adda river basin is presented. It is computed by applying the anomaly method to a qualitychecked and homogenized observation database. The reconstruction accuracy and its evolution over the study period is evaluated at both station and grid-cell levels. The anomaly-based interpolation provides rather robust estimates even for the early years of sparse station coverage with basin precipitation reconstruction errors around $10 \%$. The Theil-Sen trend analysis on the basin precipitation series shows significant (Mann-Kendall $p$ value <.05) long-term tendencies of $-3.8 \pm 1.9 \%$ and $-9.3 \pm 3.8 \%$ century $^{-1}$ for annual and autumn precipitation, respectively, even though the annual trend is not significant by excluding the first decades from the evaluation. As the basin precipitation record is expected to be underestimated due to the rain-gauge snow undercatch, the monthly precipitation fields are subjected to a correction procedure which allows to derive the multiplicative correcting constant to be applied to the basin annual precipitation series. The comparison between 1845 and 2016 yearly corrected precipitation and runoff records highlights current annual water losses of about $400 \mathrm{~mm}$ while the annual runoff coefficients exhibit a long-term significant decrease of $-6.4 \pm 1.0 \%$ century $^{-1}$. This change in the hydrological cycle is mostly to be ascribed to the strong long-term reduction in annual runoff values $\left(-11.8 \pm 3.2 \%\right.$ century $\left.^{-1}\right)$ driven by increasing evapotranspiration due to both temperature increase and, likely, land-use changes.
\end{abstract}

\section{K E Y W O R D S}

anomaly method, secular precipitation, long-term trend, runoff comparison

\section{1 | INTRODUCTION}

Alpine region is particularly prone to global warming, showing a significantly higher temperature trend than the Earth's average one. Indeed, the HISTALP database, one of the best archives of secular meteorological series in the world (e.g., Auer et al., 2007) gives evidence of a temperature increase of about $1.5^{\circ} \mathrm{C}$ in the last 150 years, recorded both at low and high-elevation areas (Böhm et al., 2001; Brunetti et al., 2009). Beside temperature 
trend, also precipitation variability and changes in its seasonality over the Alpine region were documented in the scientific literature (e.g., Schmidli et al., 2002; Casty et al., 2005; Brunetti et al., 2006a).

The climate change poses a severe threat to the Alpine hydrological system, causing a significant pressure on the key role that Alps have for water storage and supply with potential impacts on economic activities, such as agriculture, energy and industrial production, also on downstream regions (Schaefli et al., 2007; Viviroli et al., 2007; EEA (European Environment Agency), 2009; Beniston, 2012; Fatichi et al., 2014).

To face this problem, it is crucial (1) to investigate the spatio-temporal evolution of precipitation over Alpine areas on secular time scales, (2) to assess long-term areal precipitation records for the main Alpine catchments, and (3) to compare them with the corresponding runoff records. The latter allows in fact to highlight the effect of temperature induced changes in the occurrence of solid and liquid precipitation and its seasonality, in the snow water equivalent, as well as in the contributions of evapotranspiration and melting glaciers on the water disposal.

High-resolution datasets of monthly precipitation have been recently produced over the Alpine region, for example, by Efthymiadis et al. (2006) for the period 1800-2003 at 10-min spatial resolution and by Masson and Frei (2016) for the period 1901-2008 at $5 \mathrm{~km}$ resolution, while Isotta et al. (2014) provided a 1971-2008 daily dataset at $5 \mathrm{~km}$ grid spacing. High-resolution analyses of precipitation were also provided over smaller Alpine domains, such as by Brugnara et al. (2012) and Golzio et al. (2018) for the central European Alps, by Gyalistras (2003) for Switzerland and by Durand et al. (2009) for the French Alps. Among the gridding methods which have been proposed so far, the so-called "anomaly method" is one of the most applied approaches (e.g., New et al., 2001; Mitchell and Jones, 2005). All the gridding procedures aim at projecting the in-situ observations onto the cells of a regular grid, allowing to evaluate the climatic signal for a number of points which can be of several orders of magnitude larger than the number of the available rain-gauges. The long-term analyses performed on both monthly and daily scales revealed spatially heterogeneous trends in total precipitation and in statistical indexes over the Alps (e.g., Brunetti et al., 2006a; Scherrer et al., 2016; Pavan et al., 2018). Besides spatial variability, trend slope and significance were found to be dependent also on the examined period, suggesting the need of continuous update for both present and past years (see e.g., Brugnara et al., 2012).

In this framework, we applied the anomaly method to reconstruct a 30-arc sec resolution dataset of 1800-2016 monthly precipitation records for an area centred over the upper part of Adda river basin, an important water reservoir in the Central Alps for a wide portion of Northern Italy. This area is covered by a relevant number of long meteorological observations and it has one of the longest daily runoff records in Italy which has been recently recovered over the period 1845-2016. This record is presented and analysed (Ranzi et al., this issue) in the second part of the multi-century meteohydrological analysis for the Adda river basin of which this paper is the first part. The upper part of Adda river basin represents therefore a very interesting region to better investigate the response of Alpine water resources to climate variability and change.

The computed precipitation dataset constitutes an improvement to the state of the art for this area: it is based on a very dense observation database spanning more than two centuries and containing quality-checked and homogenized series retrieved from both national and extranational sources, from new digitization activities and from the recent automatic station records, which allow to extend the reconstruction up to date and to improve the data coverage, especially at higher elevations. In the last decades in fact a relevant number of rain-gauges was established in mountainous areas where observations are requested for both hydropower production and activities of prevention of natural hazards. The availability of new records allows to reduce the general difficulty in reconstructing the precipitation signal over mountainous regions which is mainly due to the uneven coverage of observations decreasing towards higher elevations, the low availability of secular station records and the heterogeneity of precipitation gradients due to the complex interactions between atmospheric circulation and the roughness of the surface (Haylock et al., 2008). Another relevant issue to be considered is the well-known rain-gauge undercatch, especially of solid precipitation, which could lead to significant precipitation underestimations in mountainous domains (Sevruk et al., 2009).

The paper aims at presenting the dataset, at assessing the robustness of the gridding method in relation to the development of the station network and at describing the multi-century record of areal precipitation extracted from the monthly gridded fields for the upper Adda river basin. This record is then analysed to investigate the trends and variability in precipitation regime over the basin and to perform the comparison with the 1845-2016 runoff coefficient. The monthly database allowed to extend the precipitation reconstruction back to 1800 and the availability of total areal precipitation values for the basin over the first half of the 19th century could represent a helpful proxy-data to estimate runoff even when this information was not yet collected. All the analyses were performed on monthly resolution due to the low 
availability of daily precipitation data before 1951, which are still stored in hardcopy yearbooks.

\section{2 | MATERIALS AND METHODS}

\section{1 | The study area}

This study focuses on an area centred on the upper part of the Adda river catchment $\left(45.6^{\circ}-46.7^{\circ} \mathrm{N}\right.$ and $8.8^{\circ}-$ $10.7^{\circ} \mathrm{E}$, Figure $\left.1 \mathrm{~b}\right)$. This area will be called thereafter "study domain", while the word "study basin" will be used to refer to the upper basin of the Adda river (the region bordered by the yellow line in Figure 1b), which is one of the main tributaries of Po river. The study basin includes an area of $4,508 \mathrm{~km}^{2}$ mostly located over the southern Alpine ridge in Lombardy, from the Rhaetian Alps to the Lake Como outlet in Lecco. The region is characterized by a very heterogeneous orography, which is predominated by the mountain environment and includes some of the main glaciers of the Central Alps contributing, to limited extent, to the annual hydrological cycle of the study basin. A more detailed description of the study basin and of the water uptake regulation is provided in the companion paper (Ranzi et al., this issue).

\subsection{The observation database}

The database used to compute the study domain gridded dataset of 1800-2016 monthly precipitation series was set up by starting from the collection of monthly
F I G URE 1 Spatial distribution of the available stations over (a) the larger area surrounding the study domain and (b) inside it. In panel (a) only the station series starting before 1861 are shown with series starting before 1811 represented by black points, in panel (b) all the available records are reported together with the corresponding starting year [Colour figure can be viewed at wileyonlinelibrary.com]
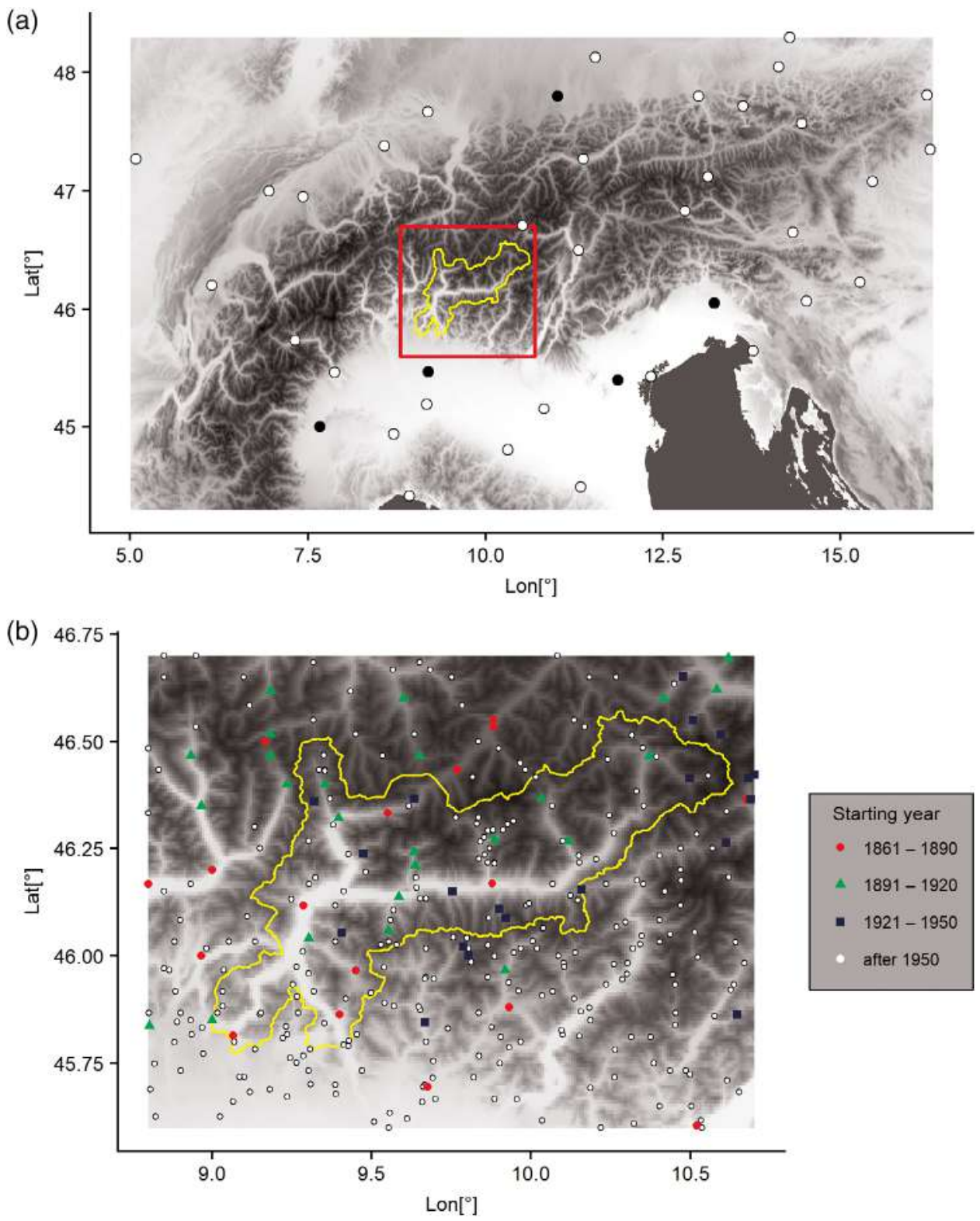
precipitation records performed by Crespi et al. (2018) which is mainly based on the archive of the former Italian Hydrographic Service (Servizio Idrografico, SI). Two different data collection approaches were used for the study domain (Figure $1 \mathrm{~b}$ and red bordered region in Figure 1a) and for the outer area (Figure 1a).

The data availability over the study domain was improved by:

- including the Trentino-Alto Adige/Südtirol monthly records provided by the digitization project "Before 1921" (https://before1921.wordpress.com). These new data allowed to extend into the past 37 series previously available only from 1921 and to add two new records;

- digitizing new data from the yearbooks of the former SI (Servizio Idrografico, 1920; 1925; 1959). 28 series previously available only from 1951 were extended in the past. The records to digitize were selected by prioritizing the stations of the study domain with the longest time coverage and located at the highest elevations;

- performing a new download of all the precipitation records available for the study domain from Meteotrentino (updated to April 2017) and from MeteoSwiss (updated to September 2017). In case of available homogenized Swiss station series, they were preferred to the original versions;

- collecting all precipitation records provided by the mechanical and automatic stations of the Regional Environmental Protection Agency (ARPA) and the Geological Monitoring Centre (CMG) of Lombardy. The records of automatic stations were merged with those of the mechanical ones allowing to overcome the general fragmentation of records occurring at most Italian sites since the 1980s, due to the transition from manual to automatic monitoring systems as well as the transition of the national rain-gauge network from SI to the Italian regional agencies.

The precipitation station records inside the study domain are indeed the most relevant ones for the present work. However, no data are available over this area before the 1860s and the station coverage remains quite sparse over the following decades too. In order to improve the observation availability and to get reliable information about the climate evolution also for the ancient years, it was necessary to include in the data collection activities a wider region around the domain. For this region, all the longest series available from the monthly homogenized archives of MeteoSwiss and HISTALP (Auer et al., 2007) were considered together with the homogenized versions of some of the longest Italian precipitation records starting in the 18th century or in the first half of the 19th century (Brunetti et al., 2006b). These stations allow the evaluation of the precipitation signal for the study domain in the earliest period, while they provide a marginal contribution to the reconstruction in the following decades when the station coverage over the study domain increases.

The collected series were checked for quality and homogeneity, except for the ones derived from already quality-controlled and homogenized archives. The quality-check procedure was performed, as described in Crespi et al. (2018), by comparing each measured series with a simulated one by means of neighbouring observations. High errors in the comparison allowed to remove gross errors such as outliers, spurious sequences of null values and digitization oversights. The series showing high deviations from the reconstructions and those with less than 10 years of data were definitely discarded from the database. When more than one source was available for the same site, the record with the longest time coverage and/or the highest quality was retained.

The homogeneity was then evaluated by applying the Craddock test (Craddock, 1979) on more than 400 monthly series with at least 20 years of data and, in case of relevant breaks, the homogenization was performed. 125 series containing on average 85 years of data were homogenized by identifying more than 300 breaks.

The final monthly database contains 338 precipitation series inside the study domain and 102 inside the study basin, while the stations outside the study domain with data before 1861 are 54, with 10 stations having data before 1811, represented as black points in Figure 1a. 120 series contain more than 120 years of data and 14 out of them are located within the study domain. The time evolution of the data availability for the study domain and study basin is shown in Figure 2. The first stations operating inside the study domain started in 1861 and in 1873 inside the study basin. The station density increased significantly from the beginning of the 20th century thanks to the contribution of the new meteorological network managed by SI. After the difficulties due to the World War II, the greatest station availability is reached, especially from 1951 to the end of the century when SI was closed and the Italian national network was fragmented into regional and subregional Agencies with the concurrent transition from the mechanical to automatic monitoring systems.

The inter-station distance, that is, the mean distance between each station and the closest one, over the whole area spanned by the database decreases gradually from about $150 \mathrm{~km}$ in the first decade, when less than 10 stations are available, to about $60 \mathrm{~km}$ in 1860 when 53 raingauges were operating and to $25 \mathrm{~km}$ in 1900 with more than 250 records. During the 20th century this value reduces further reaching about $8 \mathrm{~km}$ within the study 
F I G U RE 2 Availability of monthly records over the study domain (solid line) and the study basin (dashed line)

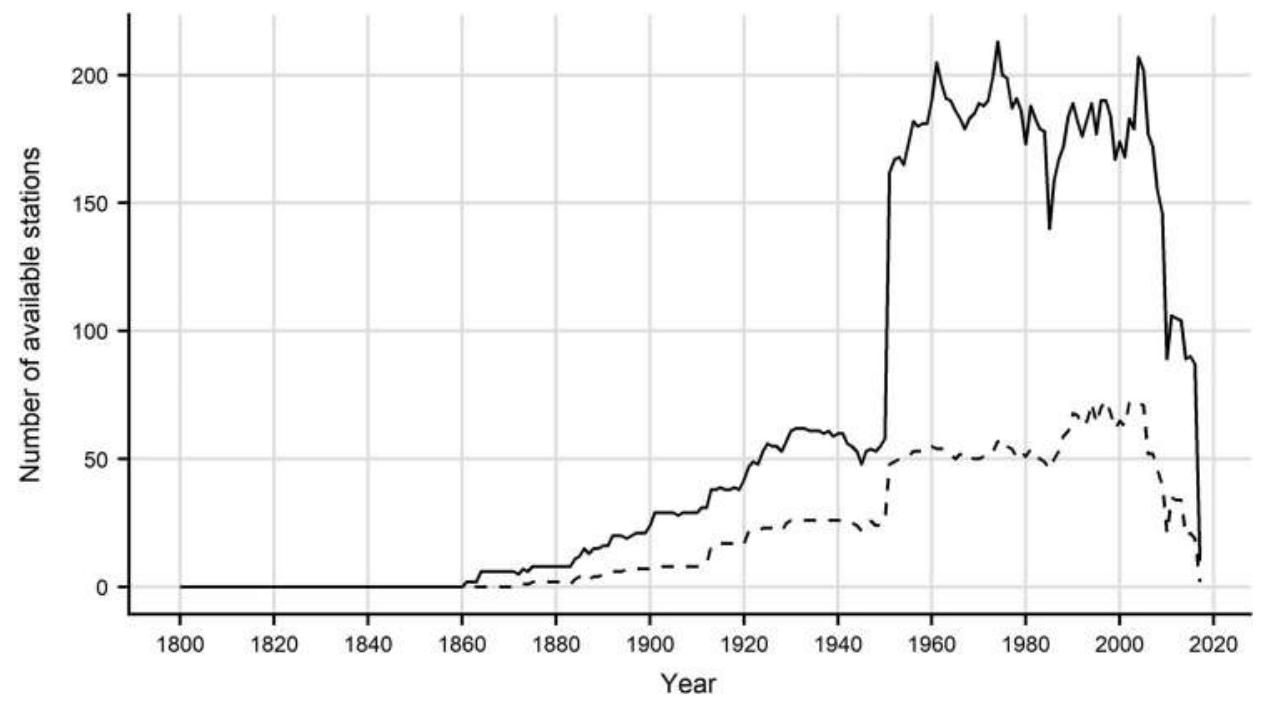

domain in the decades of maximum data availability (1951-2000).

The rain-gauge density varies significantly over the years also on altitude ranges. Most of the ancient sites are located at low elevations and the distribution gradually becomes more homogeneous over all the elevation bands in the 20th century. Despite of the increment of data availability for the highest elevations, the coverage of in situ data is still low or even missing for a relevant fraction of the grid cells located above $2000 \mathrm{~m}$ a.s.l. which are about $30 \%$ of study area grid cells.

\section{3 | The interpolation scheme: From rain-gauge network to gridded records}

The gridded dataset of 1800-2016 monthly precipitation records over the study domain was reconstructed on a 30-arc sec resolution digital elevation model (DEM) by means of the anomaly method. In this scheme the precipitation signal is reconstructed by superimposing the spatial fields of monthly climatologies and the spatio-temporal fields of relative anomalies. The two fields are computed separately and the final monthly estimate is obtained by their product.

The monthly precipitation climatologies were constructed over the 1961-1990 period corresponding to the 30 years of maximum data availability. The station monthly normals were computed after completing the gaps of the series over the reference period and the resulting data density is on average one station per $53 \mathrm{~km}^{2}$. They were then interpolated onto the DEM by means of a local weighted linear precipitation-elevation regression (LWLR) as described in Crespi et al. (2018). In LWLR the precipitation-elevation relationship is allowed to change for each grid cell. In fact, precipitation-elevation relationship is estimated for each 30 arc sec grid cell of the domain by choosing the most appropriate set of stations taking into account the topographic similarities between the stations and the grid cell itself, in terms of radial distance (rad), vertical distance (h), slope steepness (st), slope orientation (facet) and distance from the sea. In order to take into account the actual spatial scales at which the interactions between atmospheric circulation and orography are expected to occur, a smoothed DEM version was used where the terrain details are reduced but retaining the original horizontal step of $30 \mathrm{arc} \sec$ (Daly et al., 2002; Foresti et al., 2018; Crespi et al., 2018).

To compute the anomaly fields the station monthly records over the period 1800-2016 were converted into monthly relative anomalies, that is, the ratio to their corresponding 1961-1990 normals, and they were interpolated over the DEM by means of a weighted averaging scheme. In this method, the relative anomaly for a certain month and grid cell is defined by the weighted average of the surrounding station anomalies whose weights are expressed as the product of Gaussian functions depending on radial and vertical distance from the target point (Brunetti et al., 2012). The halving distance of the radial weight was defined year-by-year according to the evolution of data availability over the whole period. In particular, it corresponds to the mean radius of the circle centred on the grid cells and containing at least three stations with valid observations. The value rapidly decreases from about $200 \mathrm{~km}$ during the earliest years to about $20 \mathrm{~km}$ in 1900 and further to $10 \mathrm{~km}$ after 1951 up to present. This approach allowed to exploit the fine-scale information provided by the period of dense data coverage and to include the available records on a larger area when stations are sparser (Brunetti et al., 2012). The halving factor for the weight of elevation difference was set to 2,250 m over the whole period on the basis of a minimization error procedure. Since it is relatively high, the 
station weights are mainly defined by the nearness to the considered cell.

The 1800-2016 monthly precipitation records in absolute values over the grid were finally obtained as the product of the 1961-1990 monthly climatologies and the interpolated series of monthly anomalies. As examples of the resulting fields, in Figure 3 the precipitation distribution for the months featuring the highest total areal monthly precipitation sum on the study basin over each 40-year subperiods from 1861 to present are reported together with the available station records. The figure highlights also the gradual increase of data coverage over the study domain which passes from eight stations for September 1882 to almost 200 stations in October 1960.
The 1800-2016 monthly areal precipitation record of the upper part of the Adda river basin was obtained as follows:

$$
q_{t}=\sum_{j} p_{j, t} \cdot S_{j} \cdot f_{j}
$$

where $q_{t}$ is the areal precipitation for the time step $t, p_{j, t}$ is the precipitation reconstructed for the time step $t$ at the grid cell $j$ and $S_{j}$ and $f_{j}$ are the cell area and the fraction of cell belonging to the basin, respectively. In order to express the precipitation record in millimetres, the computed values were finally normalized by the basin total surface.

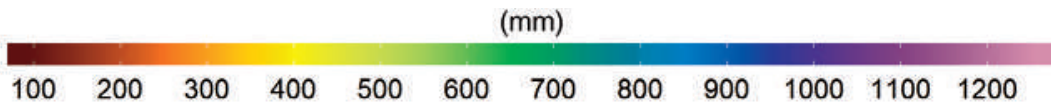

(a)

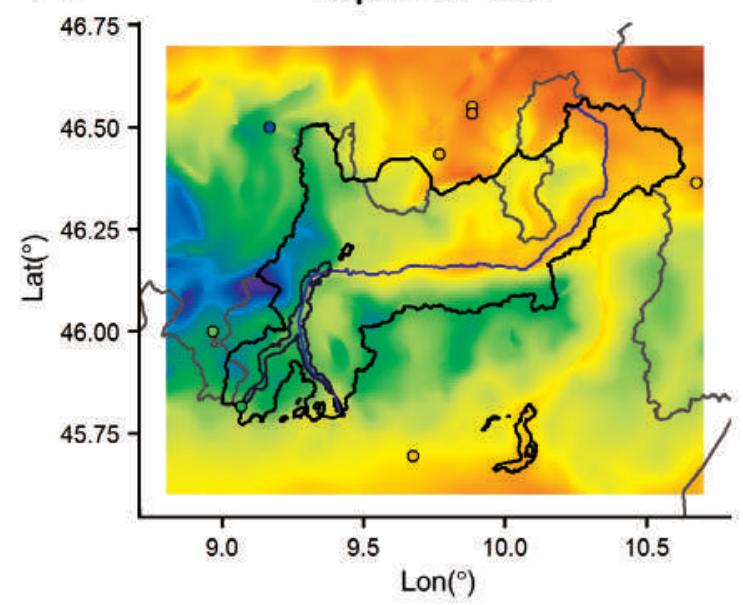

(c)

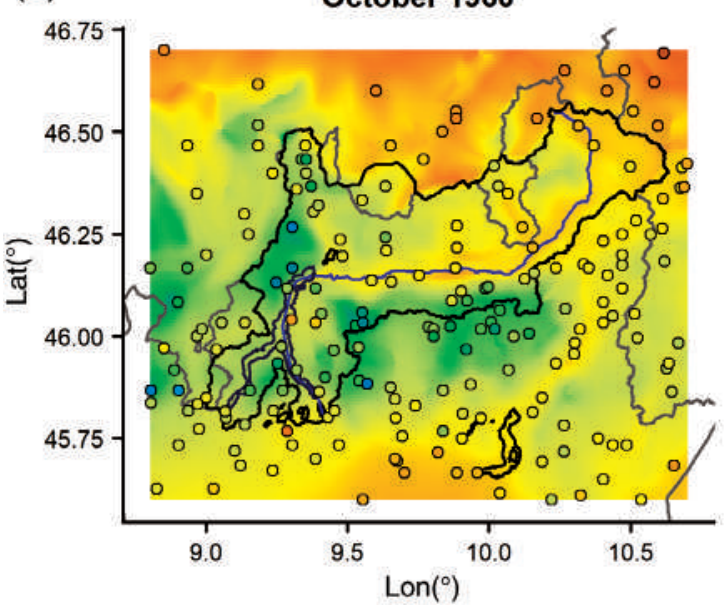

(b)

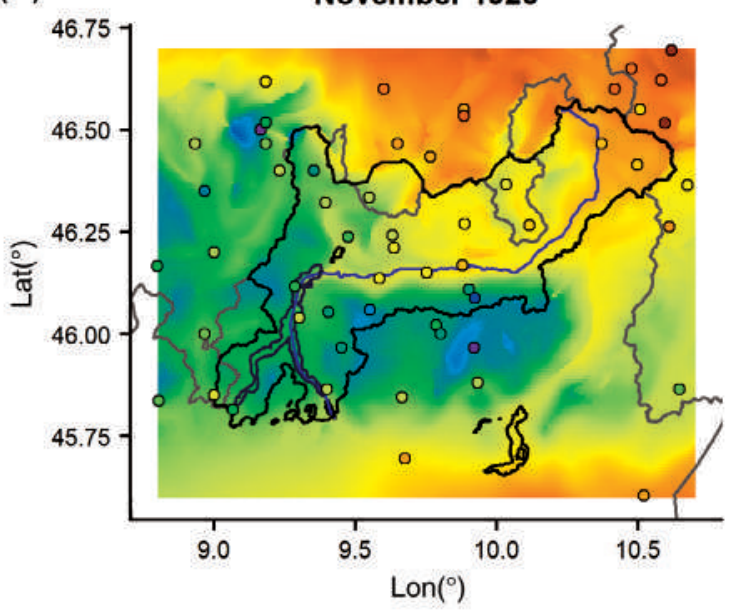

(d)

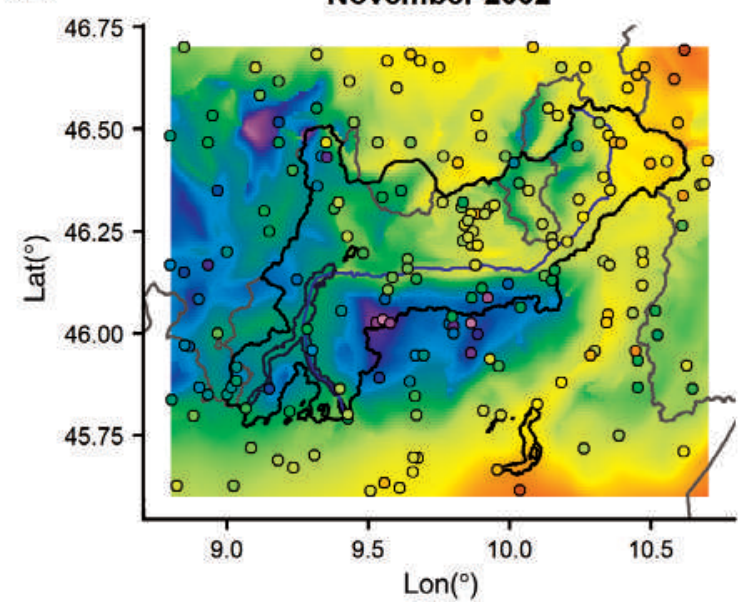

F I G U RE 3 Monthly precipitation fields corresponding to the greatest total areal precipitation values over the study basin for the subperiods (a) 1861-1900, (b) 1901-1940, (c) 1941-1980, (d) 1981-2016. The points represent the monthly records at the available station sites 


\section{$2.4 \quad$ Validation of gridded data and basin precipitation series}

The accuracy of the climatologies was assessed by reconstructing in leave-one-out (LOO) approach the 1961-1990 monthly normals of the 338 stations inside the study domain, that is, by excluding the observation under reconstruction in order to avoid self-influence. The same LOO reconstruction was also applied on the monthly anomaly series of the 338 stations within the study domain in order to evaluate the agreement between the modelled anomalies and the observed ones. The errors were evaluated in terms of mean error (BIAS), mean absolute error (MAE), mean absolute percentage error (MAPE) and root mean square error (RMSE).

However, the reconstruction errors of monthly records could be computed only from 1864, because no record is available for the study domain until 1861 and the data coverage before 1864, when most Swiss raingauges started operating, is not enough to provide a significant evaluation of the reconstruction ability at station sites. In order to evaluate the reconstruction accuracy of the anomaly gridding procedure also over the early years, an iterative procedure was performed. The period 1801-1950 was divided in 30 consecutive 5-year intervals and the 1951-2000 monthly anomalies of all the stations in the study domain were iteratively reconstructed in LOO approach by considering only the records of the stations operating in each 5-year subperiod. The 1951-2000 period was chosen as reference as it corresponds to the years of best station coverage. The same halving distance coefficient, already computed for each year whose data availability is considered (see Section 2.3), was used and whenever a station record selected for the reconstruction did not cover the period 1951-2000 the anomalies of the nearest available station were used in order to prevent the reconstruction from being biased by the missing data. The reconstruction errors were computed by comparing the measured 1951-2000 monthly anomalies of each station in the study domain with the corresponding simulated series obtained by varying the data coverage.

The same procedure was applied also to evaluate the uncertainty evolution of the monthly basin precipitation record in relation to the rain-gauge coverage variation over the study period. Since the actual monthly total precipitation series over the basin is unknown, the estimated values over the 1951-2000 period of best data availability were considered as reference since they are expected to be characterized by the highest robustness. The 1951-2000 monthly basin precipitation record was then iteratively reconstructed by computing the monthly anomaly fields only from the data of the available stations in each 5-year subperiod from 1801 to 1950. At each iteration, the gridded dataset was rescaled to absolute values by means of the 1961-1990 climatologies and Equation (1) was applied to get the areal precipitation estimates which were compared to the reference one. In particular, MAPE values were computed for each iteration as follows:

$$
\operatorname{MAPE}_{i}=\frac{1}{T} \cdot \sum_{t=1}^{T} \frac{\left|\tilde{q}_{t, i}-q_{t}\right|}{q_{t}} \cdot 100
$$

where $\tilde{q}_{t, i}$ is the simulated basin precipitation for time step $t$ by considering the station availability in subperiod $i, q_{t}$ is the reference precipitation value at time $t, T$ is the total length of the series and $t$ runs from January 1951 to December 2000.

\section{3 | RESULTS AND DISCUSSION}

\section{1 | Climatologies, anomalies, and precipitation records}

The error values of 1961-1990 monthly climatology reconstruction are listed in Table 1. BIAS is almost null in all months with a slight underestimation in summer. Despite the lowest MAE values, which are mainly due to the drier conditions, the model is affected by the greatest uncertainty in winter, when MAPE reaches the maximum in January (16\%). The greater MAPE in winter

T A B LE 1 Monthly leave-one-out reconstruction errors of the 1961-1990 normals for the 338 stations included in the study domain

\begin{tabular}{|crrrl|}
\hline Month & BIAS & MAE & MAPE [\%] & RMSE \\
\hline 1 & 0.0 & 9.1 & 15.6 & 12.5 \\
\hline 2 & 0.4 & 7.9 & 14.0 & 11.0 \\
\hline 3 & 0.2 & 9.8 & 12.4 & 14.5 \\
\hline 4 & -0.1 & 13.7 & 12.1 & 20.5 \\
\hline 5 & -0.4 & 14.8 & 9.6 & 20.6 \\
\hline 6 & -0.3 & 12.6 & 9.3 & 16.6 \\
\hline 7 & -0.3 & 11.0 & 9.0 & 14.1 \\
\hline 8 & -0.5 & 11.1 & 8.0 & 14.8 \\
\hline 9 & -0.2 & 11.8 & 10.0 & 16.0 \\
\hline 10 & 0.0 & 13.0 & 10.7 & 18.1 \\
\hline 11 & -0.2 & 13.6 & 12.3 & 20.3 \\
\hline 12 & 0.2 & 8.0 & 14.3 & 11.6 \\
\hline
\end{tabular}

Note: Except for MAPE, all the values are expressed in mm and BIAS is defined as the difference between simulation and observation. 
could be partly ascribed to the difficulties in measuring the contribution from solid precipitation in high-elevated areas. The wind-induced undercatch is in fact one of the main causes of precipitation underestimation at mountain sites, which are mostly exposed to intense winds and snowfall events (Sevruk et al., 2009).

As regards the annual precipitation climatology (Figure 4), the mean annual precipitation normals for the study domain and the study basin are $1,314 \mathrm{~mm}$ and $1,296 \mathrm{~mm}$, respectively. The driest area is located over the North-Eastern part of the study domain along the Venosta Valley where a rain shadow effect occurs leading to less than $500 \mathrm{~mm}$ year ${ }^{-1}$, while the highest precipitation values occur over the western portion of the study domain over the Como Prealps and the Canton of Ticino with annual maxima exceeding $2,000 \mathrm{~mm}$, especially around the San Bernardino Pass. Other wet conditions are evident over the Orobian Alps, South of the basin, with annual totals ranging between 1,600 and 2,000 $\mathrm{mm}$, while the innermost part of Valtellina is characterized by lower precipitation values, especially around Sondrio, where annual totals are below $800 \mathrm{~mm}_{\text {year }}{ }^{-1}$. A similar pattern is also evident along the course of Oglio river flowing South-East of the Adda basin into Lake Iseo where annual totals decrease of about $25 \%$ with respect to surrounding areas.

The driest conditions occur during winter (DJF) over the entire area, with less than $100 \mathrm{~mm}$ season $^{-1}$ over wide portions of Valtellina, Grisons and Venosta Valley (Figure 5). Except for winter, the precipitation regime is almost invariant along the year, with slightly wetter

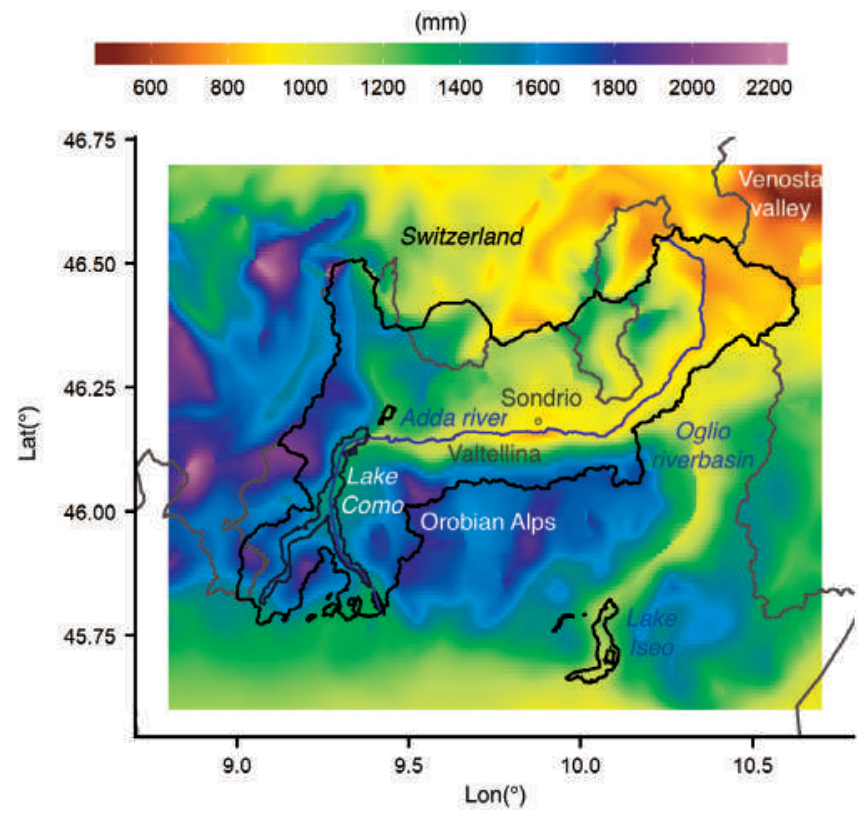

F I G U R E 4 1961-1990 annual precipitation climatologies conditions during summer (JJA) when they are mainly driven by convective phenomena enhanced by moist and warm Mediterranean air at low levels and drier and colder continental currents at higher levels. Considering the average over the grid cells of the study basin only, the precipitation normal is $170 \mathrm{~mm}$ in winter, $350 \mathrm{~mm}$ in spring (MAM), $410 \mathrm{~mm}$ in summer and $365 \mathrm{~mm}$ in autumn (SON), while the yearly cycle of monthly precipitation is characterized by the highest and rather constant contributions between April and November ( $10 \%$ of yearly values), with other months accounting for about $5 \%$ of the yearly values.

As regards the accuracy of monthly anomaly reconstruction, by considering all the available data over the study period for each month, MAE ranges from 0.24 in December to 0.14 in May, confirming the greater difficulty in capturing winter precipitation.

Figure 6 reports the time evolution along the 1864-2016 period of average annual MAE and BIAS obtained over all the available station anomalies at each time step. The highest average MAE values occur at the beginning of the considered interval with maxima around 0.30 when they are mostly affected by the low data coverage, MAE gradually reduces over the following decades to about 0.20 and it decreases further to about 0.15 from the second half of the 20th century during the period of best data availability. A slight increment is evident in the last years, probably due to the decrease of updated data for the most recent period. The evolution of average BIAS is more regular and, except for the first two decades, it is almost null over the whole period.

By applying the iterative procedure described in Section 2.4 also the influence of station density on the reconstruction accuracy was evaluated and the results are reported in Figure 7. The errors reduce significantly after 1861, when the first stations started operating inside the study domain, and the MAE distributions remain almost stable with median values around 0.2 from the beginning of the 20th century. It is worth noting that even if the coverage before 1860 leads to larger errors with medians around 0.4 , there is no further decrease in performances even for the lowest data coverage of the first years, when very few stations enter in the interpolation.

The rather low reconstruction errors obtained over almost the whole investigated period are mainly due to the large spatial coherence of anomalies which allow to estimate a reliable climatic signal even when the data density is lower. The distribution of the correlation between the anomaly records of all the station pairs within the study domain as function of their distance shows in fact correlation values above 0.7 even for distances greater than $70 \mathrm{~km}$. 
(a)
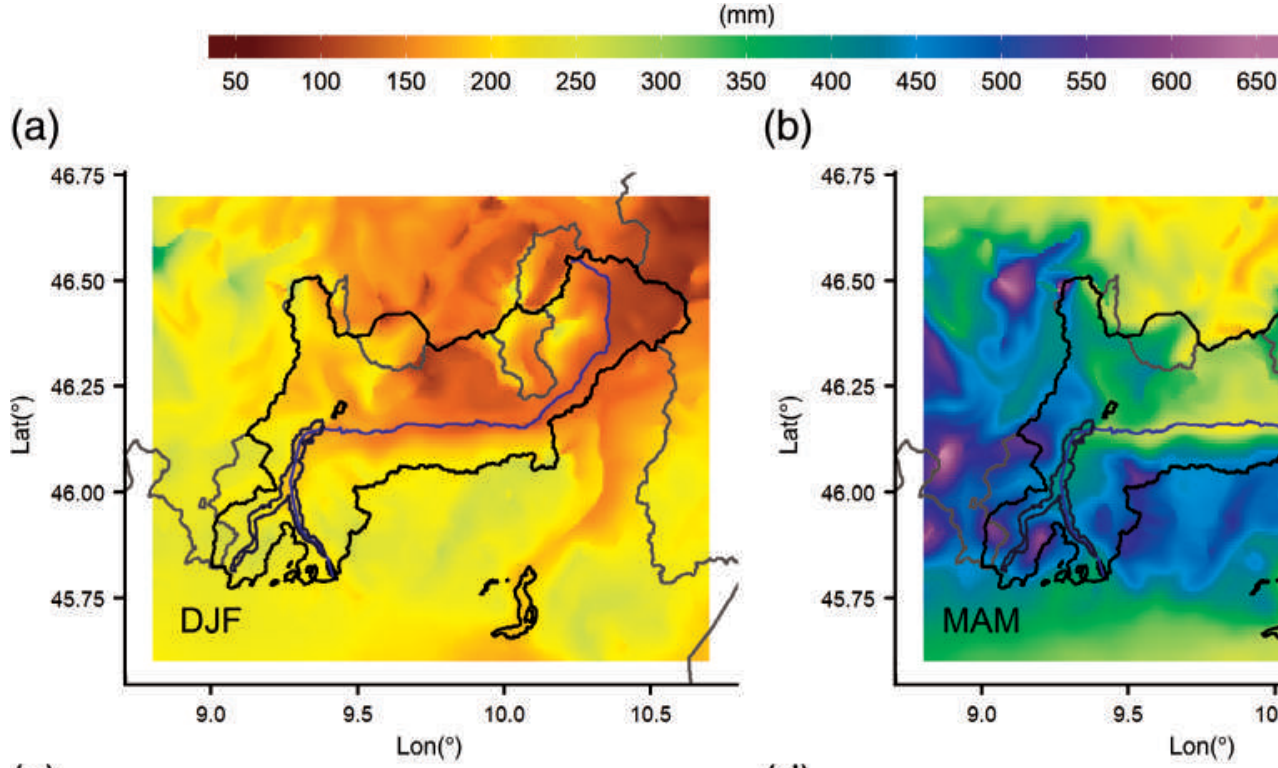

(c)

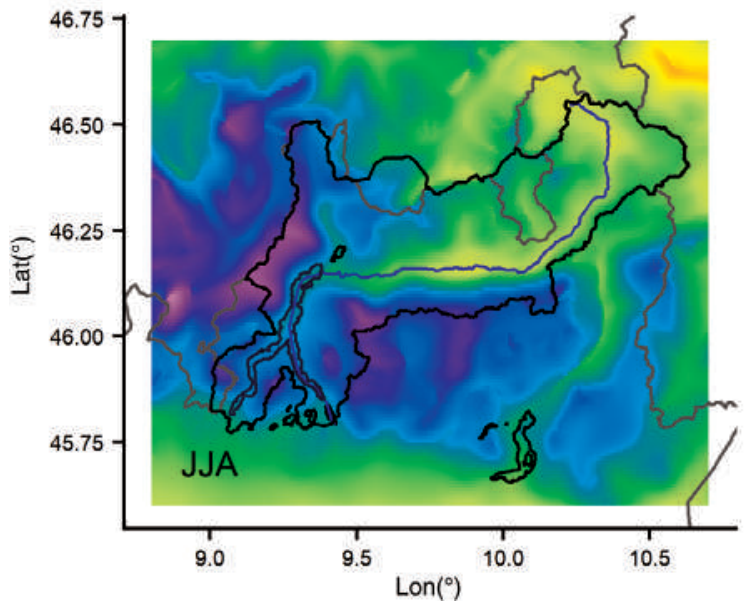

F I G U R E 5 1961-1990 seasonal precipitation climatologies

The accuracy in reconstructing the secular monthly precipitation records in absolute values was also evaluated by converting the LOO station monthly anomalies into millimetres by means of the product for the corresponding LOO normals. The largest fraction of MAPE values obtained by the comparison of the station simulations with observations over the 1864-2016 period ranges between 16 and $23 \%$ with about $20 \%$ as average value.

\section{2 | The 1800-2016 monthly areal precipitation record of the study basin}

The 1800-2016 monthly areal precipitation record of the upper Adda river basin was computed by means of Equation (1). The availability of the gridded precipitation dataset allowed to assess total precipitation falling on the (b)

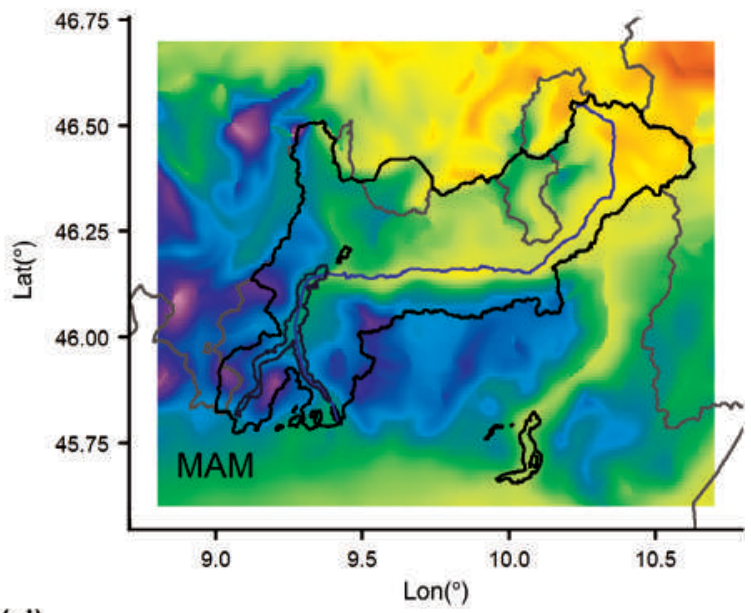

(d)

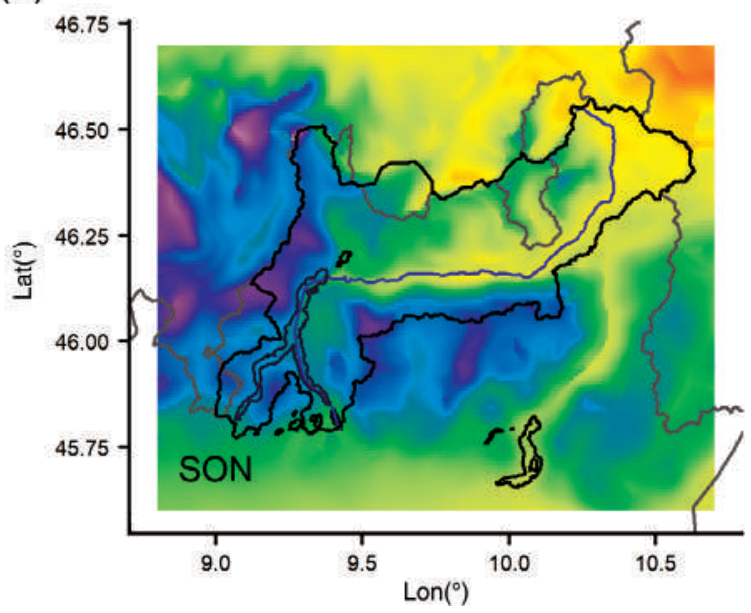

study basin at any time step over the whole considered period. This information can be retrieved by means of the anomaly method and not directly from the absolute station records only: if the monthly precipitation fields were estimated by simply interpolating the monthly records of available stations, the study basin areal precipitation would be significantly underestimated, at least before 1951. The underestimation obtained by just interpolating the monthly observations before the 1860 s is about $30 \%$ and it reduces to about $10 \%$ in the following years until 1900. After that the bias gradually decreases, even though it remains above 5\% until 1951. This outcome reflects the fact that the station distribution before 1951 is biased towards low-level areas, where also precipitation normals are generally lower than at higher elevations. The anomaly method integrates the spatial precipitation gradients contained in the climatological fields allowing to avoid 


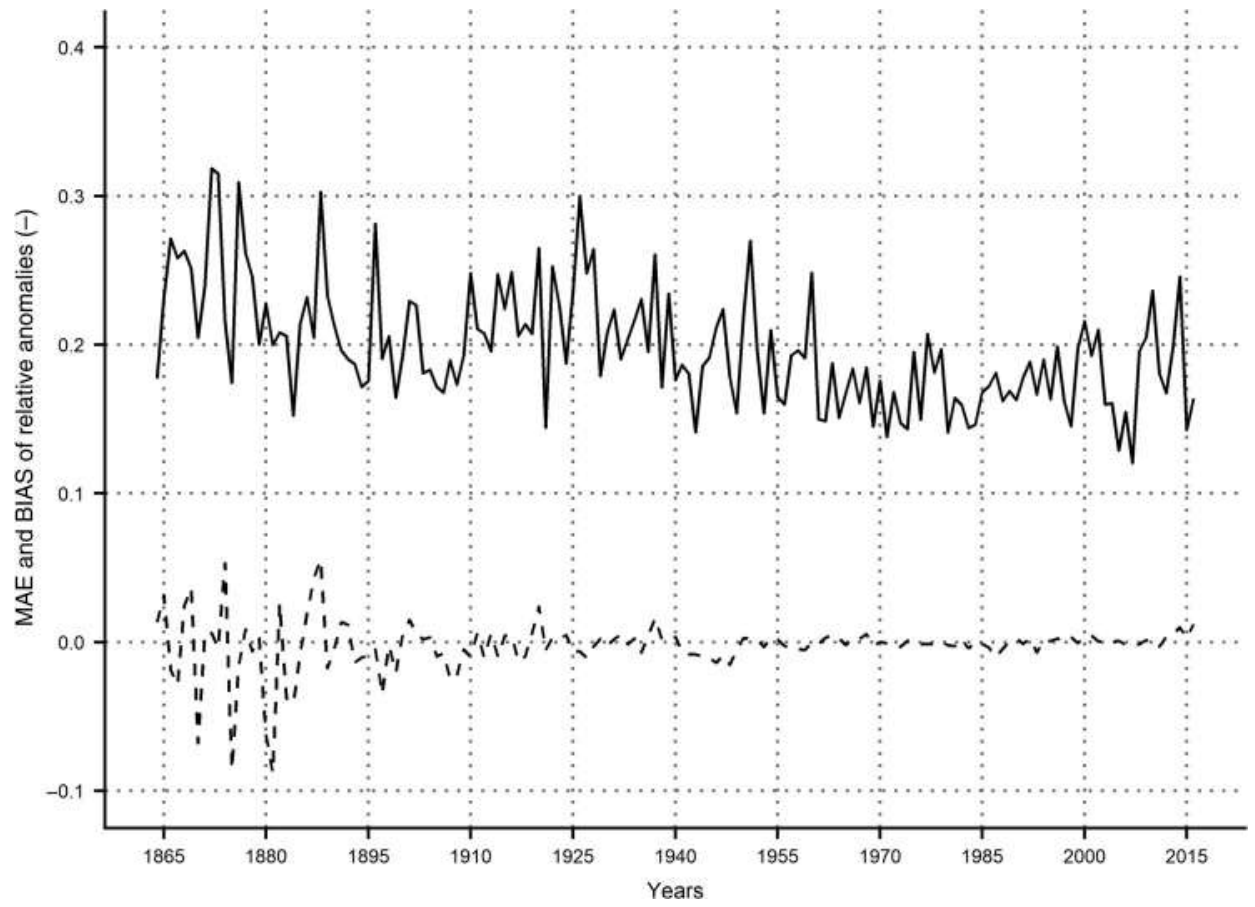

F I G URE 6 Evolution of annual MAE (solid line) and BIAS (dashed line) of leave-one-out reconstruction of the 1864-2016 station monthly relative anomalies available inside the study domain. The differences between simulated and measured station anomalies are considered

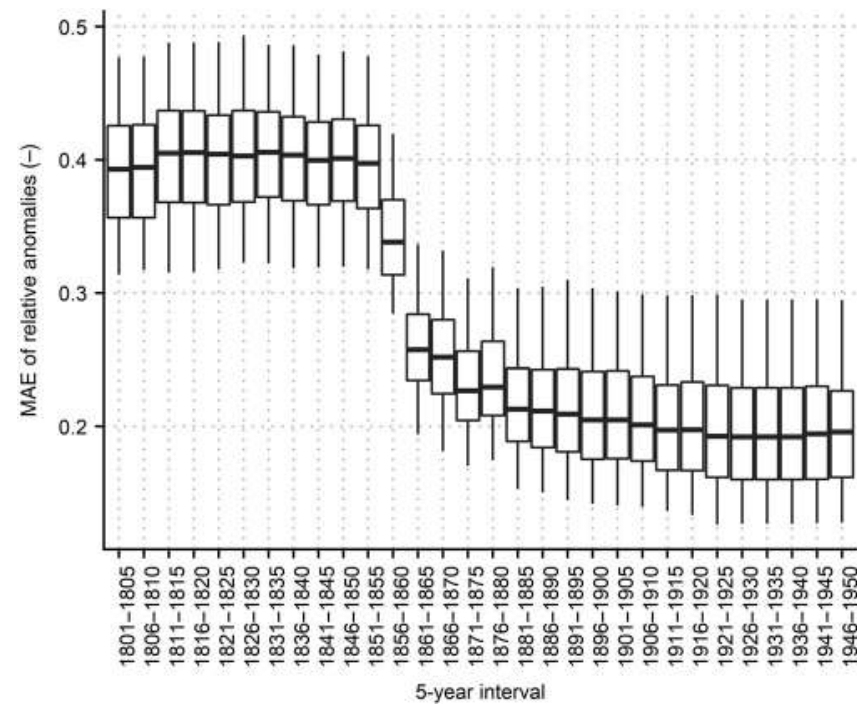

F I G URE 7 MAE distribution obtained from the reconstruction of the 1951-2000 monthly anomalies of all the stations in the study domain by considering only the records from the rain-gauges available in each 5-year subperiod from 1801 to 1950. The boxes represent the inter-quartile range and the median is reported by the bold line; the whiskers represent the 5-95\% quantile range

the bias due to the uneven station coverage in the resulting areal precipitation records for the study basin.

However, even though unbiased, the accuracy of this record varies over time. The error evolution, as obtained by means of the method described in Section 2.4, is summarized in Table 2. The MAPE (Equation 2) computed on annual scale is about $10 \%$ for all the station coverages before 1855 , it decreases to $7 \%$ by considering the data density of $1856-1860$ and to $4 \%$ with the availability of 1861-1865 when the first stations inside the study domain started operating. The annual error reduces further to $2 \%$ with the station availability from 1881 and to $1 \%$ by taking into account the network coverage from 1921. The correlation coefficients between 1951-2000 simulated and reference precipitation records on annual scale show the same behaviour as MAPE, with values above 0.90 from 1861 availability onwards.

It is worth noting that the reconstruction from the few available data of the first decades is relatively robust and errors are constantly around $10 \%$ even when less than 10 stations are used for the interpolation. In order to assess the meaningfulness of the information on the study basin retrieved from these few stations all located outside the study domain, we extracted 1,000 sets of 50 random values from a normal distribution with the same mean and standard deviation as the 1951-2000 annual precipitation series and the corresponding MAPEs were computed. The average error turns out to be about $20 \%$, which proves the consistency of the estimated accuracy and gives evidence of the ability of the database to provide a reliable climate signal over the basin even for the most remote years. Very similar outcomes are depicted also at seasonal scale. The lowest agreement is pointed out for winter with MAPE of about $30 \%$ for the data availability of the first decades, when all 
TABLE 2 Annual and seasonal MAPE values of the reconstructed 1951-2000 total precipitation series by considering the data availability in some selected 5-year subperiods from 1801

\begin{tabular}{|lllllllr|}
\hline 5-Year data availability & Year & \multicolumn{3}{c}{ DJF } & MAM & JJA & SON \\
\hline & MAPE [\%] & $r$ & \multicolumn{2}{l}{ MAPE [\%] } \\
\hline $1801-1805$ & 9.5 & 0.72 & 28.8 & 23.4 & 15.5 & 25.2 \\
\hline $1821-1825$ & 9.9 & 0.69 & 29.4 & 23.9 & 17.2 & 25.2 \\
\hline $1841-1845$ & 9.9 & 0.72 & 29.2 & 24.4 & 16.7 & 22.8 \\
\hline $1856-1860$ & 7.1 & 0.87 & 22.7 & 18.7 & 12.3 & 18.3 \\
\hline $1861-1865$ & 3.8 & 0.96 & 16.5 & 7.1 & 6.3 & 7.8 \\
\hline $1881-1885$ & 2.0 & 0.99 & 7.4 & 3.8 & 3.7 & 4.2 \\
\hline $1901-1905$ & 2.2 & 0.99 & 8.0 & 3.4 & 3.7 & 4.1 \\
\hline $1911-1915$ & 1.6 & 0.99 & 4.3 & 2.3 & 2.4 & 2.7 \\
\hline $1921-1925$ & 1.1 & $>0.99$ & 3.4 & 1.6 & 1.7 & 1.9 \\
\hline
\end{tabular}

Note: For the annual simulations only, the correlation coefficients are reported too.

the rain-gauges were located at low elevation, and it decreases below $5 \%$ only after 1910 . For the other seasons, the reconstruction errors are below $5 \%$ already from 1881, when only four stations were operating inside the study basin, and they generally reach $2 \%$ by using the data distribution after 1910.

\section{3 | Variability and trends of the multi- century precipitation record of Adda basin}

The 1800-2016 annual and seasonal precipitation records for the study basin (Figure 8) were analysed for long-term trends by performing the Theil-Sen (TS) test (Theil, 1950), while the trend significance was assessed by the MannKendall (MK) test (Kendall, 1975). Considering a significance level of 0.05 , a significant negative annual trend of $-51 \pm 25 \mathrm{~mm}$ century $^{-1}$ was pointed out, while, on seasonal scale, a negative tendency is depicted in all cases even though it turns out to be significant for autumn precipitation only with a reduction of $-40 \pm 16 \mathrm{~mm}$ century $^{-1}$. These values correspond to a $-3.8 \pm 1.9$ and $-9.3 \pm 3.8 \%$ century $^{-1}$ decrease, respectively. The 1800-2016 negative trend is likely to be largely driven by the wet conditions characterizing the beginning of the 19th century. In addition, the earliest values are more affected by uncertainty which has to be considered in the trend evaluation. In fact, excluding the first decades the annual trend remains negative, but its MK $p$ value is above 0.05 .

It is however worth considering that the long-term trend of the basin precipitation record could be slightly biased because of the changes over time of rain-gauge snow undercatch. A detailed discussion about this issue is provided in the following section, while trend estimations are performed without considering it also in order to allow the comparison with other literature results which do generally not take into account the rain-gauge snow undercatch.

In order to investigate the variability of precipitation over the basin on a finer time scale, a running-trend analysis was performed on the 1800-2016 annual and seasonal records. The TS slopes and MK significances were computed on windows of increasing width from 20 years up to the entire period spanned by the series and running from the beginning to the end of the record. The running trend on annual values (Figure 9a) confirms a negative long-term tendency which, however, assumes significance only if almost the whole period is included in the evaluation. The most frequent trend values range from -10 to $+10 \mathrm{~mm}^{\text {decade }}{ }^{-1}$ but only a low fraction of the trends has MK $p$ values below 0.05 , as shown by the pixel size. A more relevant variability in precipitation regime is evident at shorter time scales with a sequence of wetting and drying conditions, especially in the first half of the 20th century. A high frequency variability was also pointed out for seasonal records (Figure 9b-e), while only the autumn series shows a significant drying tendency at long-time scale, which persists even varying the beginning of the considered window. It is interesting to note the strong negative trend in spring precipitation series starting from the 1910s that is evident also for time windows longer than 50 years. This trend is due to the rather lower precipitation values from the 1940s which correspond to a severe hydrological drought and which are interrupted by a relevant increase in the 1970s (Figure 9c). After this decade, however, spring precipitation returns to be rather low, with another very severe drought at the beginning of the 21st century (see also Figure 8), and it shows significant negative trends even over 100-year long periods starting around the 1910s. This spring trend is also highlighted by Brugnara and Maugeri (2019). 
(a)

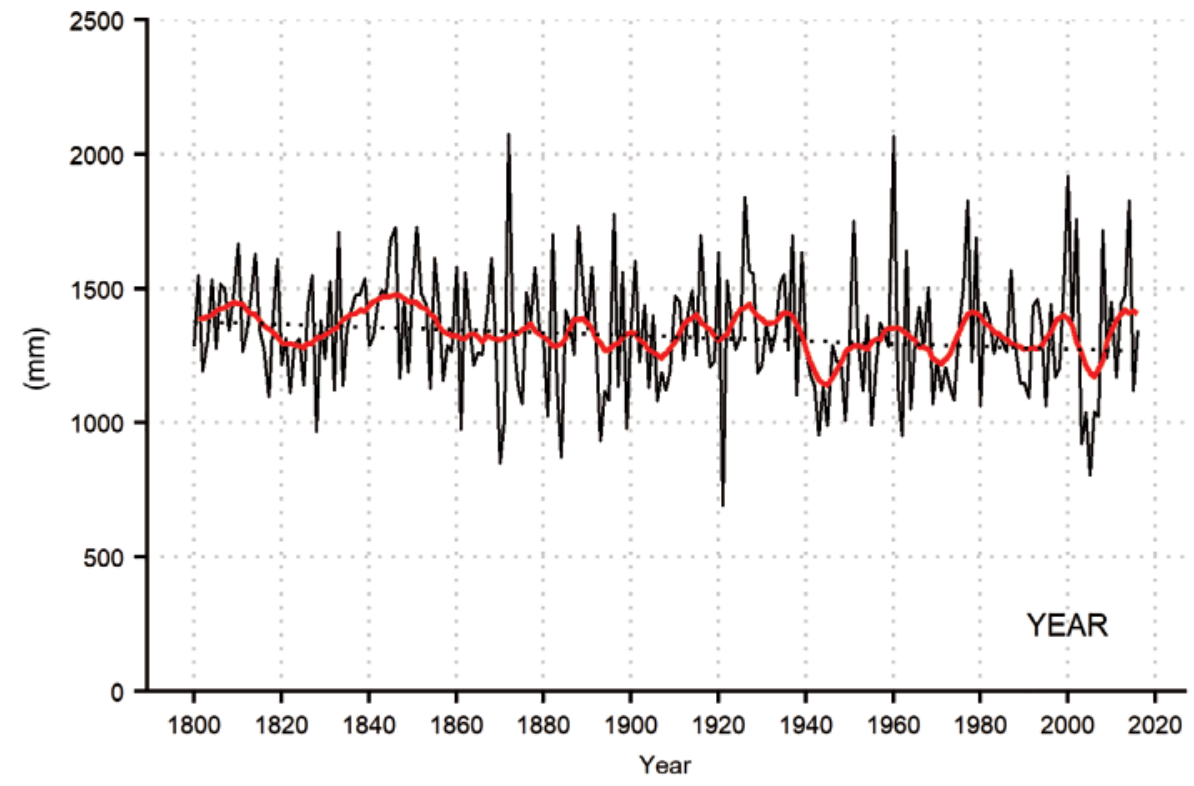

(b)

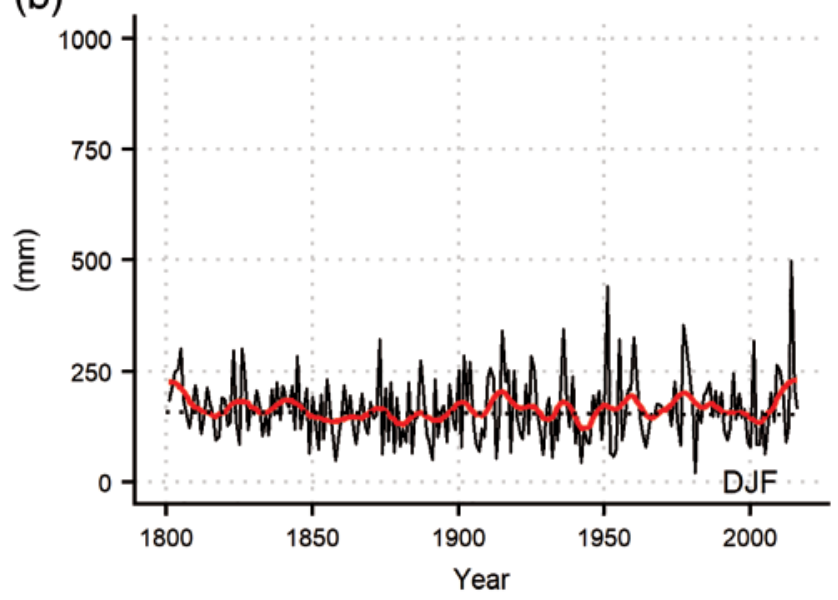

(d)

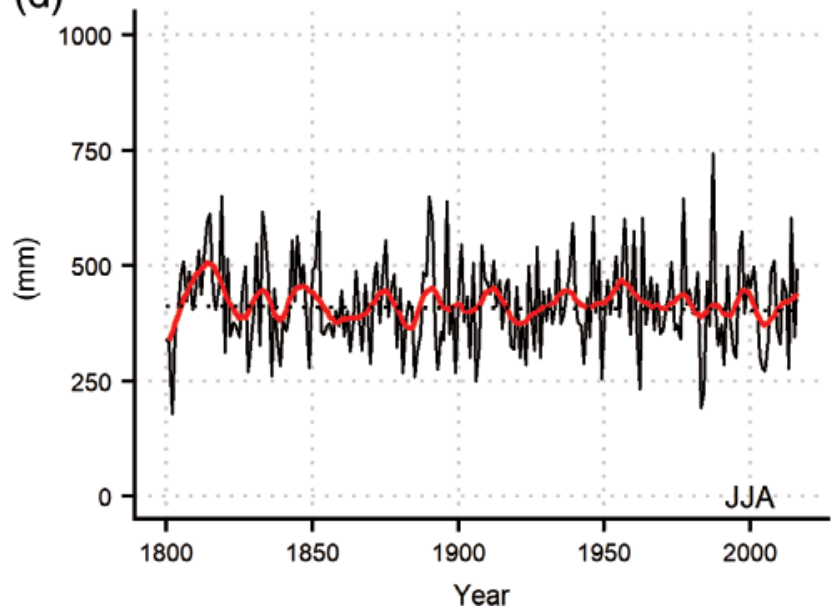

(c)

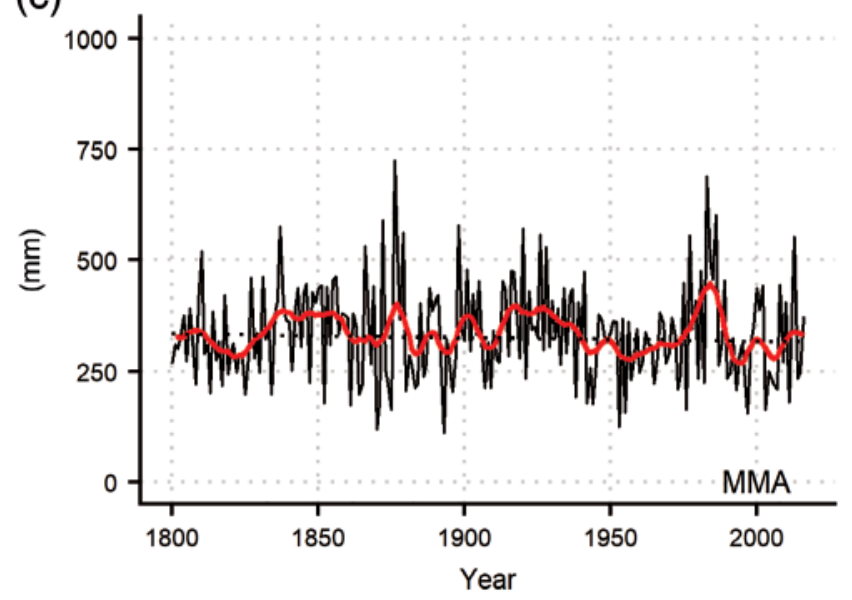

(e)

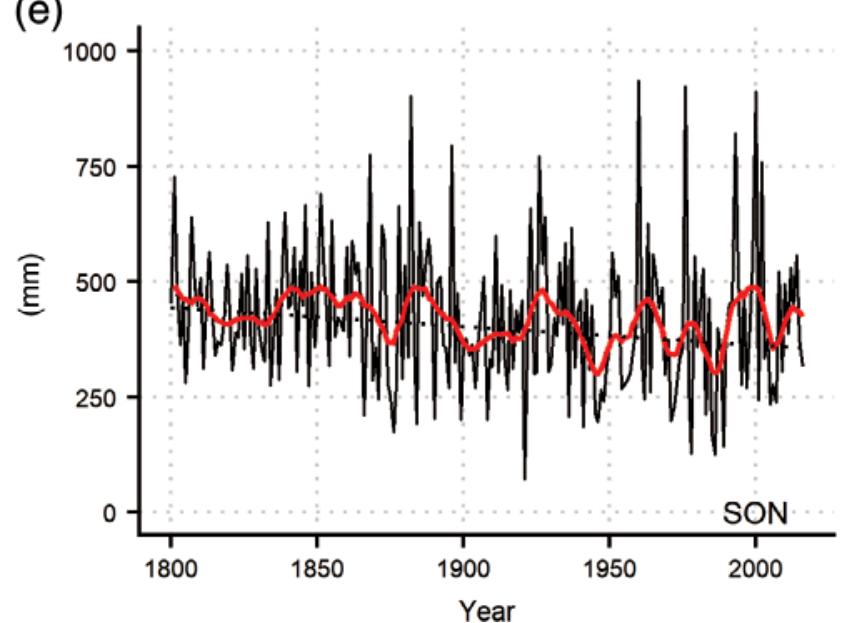

F I G U R E 8 1800-2016 annual and seasonal series of total precipitation of the upper Adda river basin (solid black line) together with a 11-year centred Gaussian filter with 3-year standard deviation (red solid line) and the Theil-Sen linear fit (dotted line) [Colour figure can be viewed at wileyonlinelibrary.com] 
(\% per decade)

(a)
$<-20 \quad(-20,-16)$
- "
$(-12,-8) \quad(-8,-4) \quad(-4,-2) \quad(-2,0) \quad(0,2)$
(1)
(
-

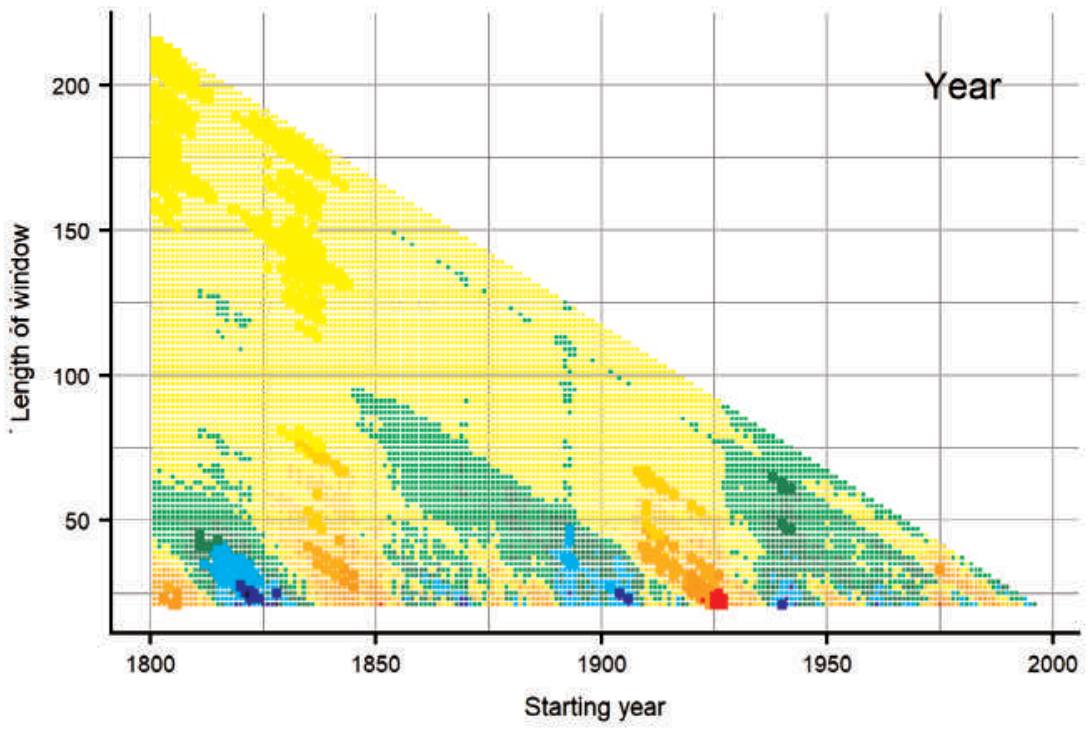

(b)

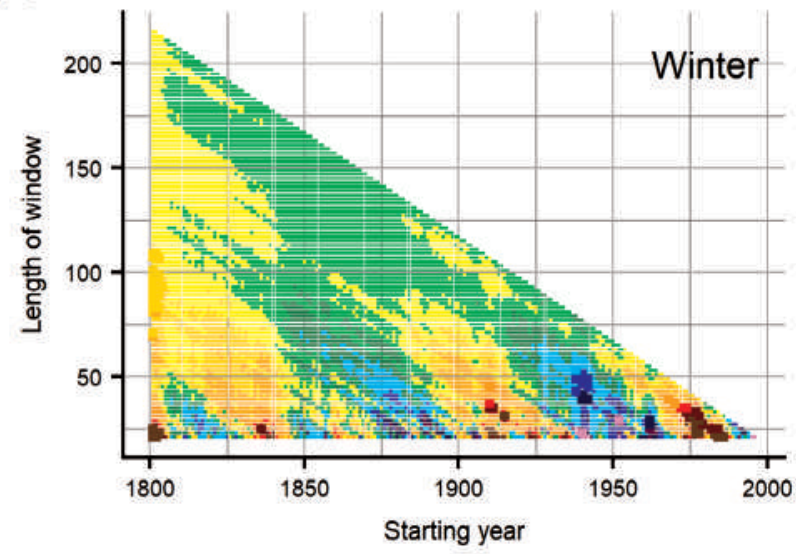

(d)

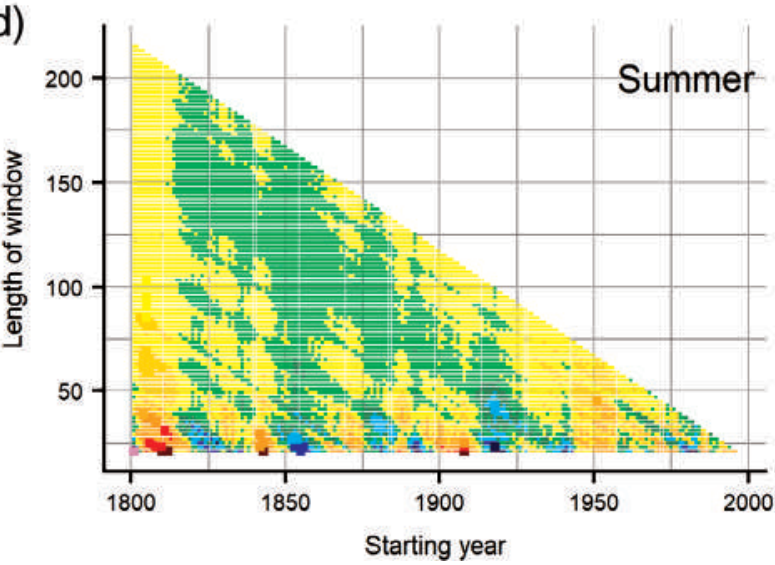

(c)

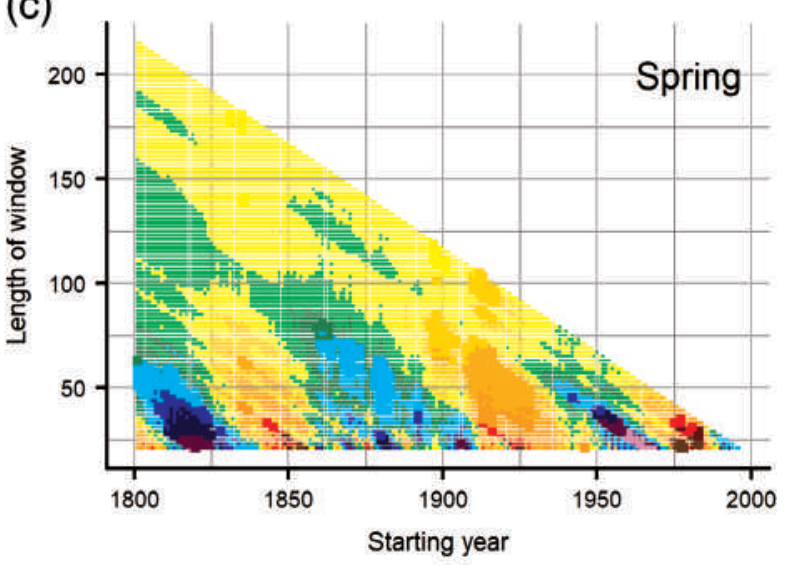

(e)

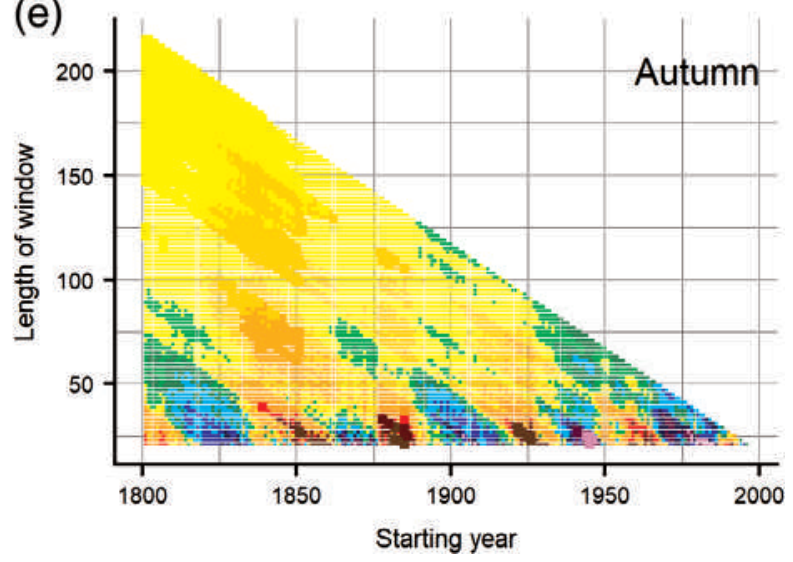

F I G U RE 9 Running trend of annual and seasonal precipitation series. Trend values are expressed by colours (green to purple positive and yellow to brown negative) while trend significance is represented by the pixel size (larger pixels for Mann-Kendall $p$ values <.05) 


\section{4 | Comparison of basin precipitation and runoff series}

Before comparing the annual precipitation series of the study basin with the corresponding runoff record (1845-2016), it is necessary to take into account the wellknown problem of rain-gauge snow undercatch, which could account for up to several tens of percents of the measured values, especially at the high-level sites characterized by higher wind speed (Sevruk, 1985; Richter, 1995; Frei and Schär, 1998). Ranzi et al. (1999) and Grossi et al. (2017) showed that the underestimation of snow precipitation for a rain-gauge network in an area including also the Adda river basin, could range between 30 and $70 \%$ depending on the location, wind velocity and instrument type.

Even though well-known, the problem of snow undercatch is very difficult to address as it is extremely site-dependent and relevant amount of station metadata and meteorological information, especially wind speed, are required to punctually provide reasonable evaluations of the undercatch. For this reason, most climatologies and precipitation analyses are performed without applying any correction at station level (e.g., Frei and Schär, 1998; Isotta et al., 2014; Crespi et al., 2018; Pavan et al., 2018): corrections which are not representative of the specificities of each station location could in fact introduce significant local errors reducing the accuracy of the interpolated fields.

In order to take anyway into account the rain-gauge snow undercatch at basin scale in the comparison with the annual runoff series, we tried to evaluate the size of this systematic bias on the annual basin precipitation series. To do this, we need to consider the different issues affecting this evaluation: (1) the snow undercatch correction should be applied only to the solid fraction of precipitation which has to be identified on the basis of the temperature of each grid cell; (2) the increase of temperature over the past decades caused a reduction of the snowfall events in some elevation bands and the consequent snow undercatch decrease along time introduces a spurious positive trend in total measured precipitation amount; (3) since the stations located at low elevation and in the inner valleys (i.e., where the solid precipitation amount and/or wind exposure are lower) are less affected by snow undercatch, its impact on the basin precipitation series varies in time, driven by temporal evolution of the spatial distribution of available stations: in the early period, for which anomalies are reconstructed from only low-level stations, the undercatch is less relevant.

In order to take into account all these issues, we firstly applied to each grid-point monthly precipitation value of the 1951-2000 period, that is, the period with maximum data availability, the correcting algorithm proposed by Eccel et al. (2012) and also used by Grossi et al. (2017) for the Adda river basin. In this scheme, a correction factor of 1.5 is introduced to increase the precipitation likely occurring in solid form (with monthly average temperature $T \leq 0^{\circ} \mathrm{C}$ ) while a linearly temperature-dependent correction is applied for precipitation likely occurring in mixed form (with monthly average $0^{\circ} \mathrm{C}<T<2^{\circ} \mathrm{C}$ ). The gridded monthly temperature records we used in this procedure were computed by applying to temperature observations the same anomaly procedure described for precipitation (Brunetti et al., 2012), exploiting the high-resolution temperature climatology published by Brunetti et al. (2014) and an improved version of the temperature time series presented in Brunetti et al. (2006b). The average ratio between the corrected and uncorrected annual basin precipitation values turned out to be 1.11 which was applied as multiplicative coefficient to correct the latter series over the entire $1800-2016$ period. The multiplicative coefficient was calculated over the 1951-2000 interval even though temperature data are available for the entire study period because the station network after 1950 provides the best representation of the whole elevation range of the study domain. Before this year the availability of high-elevation rain-gauges decreases and, especially in the first half of the 19th century, the database mainly represents low-elevation areas. The precipitation anomalies of high-elevation grid cells for this period are derived from the anomalies of low-elevation stations which are less affected by the undercatch bias: if we corrected them directly, the correction would be overestimated since it assumes undercatch contributions corresponding to highelevation grid-cell temperatures.

A further limit of the correction procedure is that it was applied at monthly scale, but the monthly average temperature provides only a rough estimation of the actual temperatures of the days in which precipitation occurs.

The comparison with the annual runoff series was performed over the 1846-2016 period on the basis of the hydrological year, that is, from September to August, in order to take into account the fraction of precipitation falling as snow during autumn and winter which is released during the following snowmelt runoff in spring and summer. This is also the 12-month period providing the highest correlation values between runoff and precipitation series, both with and without snow correction. The mean annual difference between precipitation and runoff proves the relevance of the correction: it turns out to range from about $300 \mathrm{~mm}$ in the first years to about $400 \mathrm{~mm}$ in recent decades with a mean value over the whole period of $330 \mathrm{~mm}$, which decreases to only 
$178 \mathrm{~mm}$ if the uncorrected precipitation series is considered. Since the main mechanism explaining the water loss from the basin is evapotranspiration, annual water losses below $200 \mathrm{~mm}$ seem to be strongly lower than expected. In fact, previous literature studies applying the Penman-Monteith equation at specific sites in Adda basin (e.g., Ranzi and Bacchi, 1998) and in nearby basins in Switzerland (Gurtz et al., 1999) suggest that the actual evapotranspiration over the study basin, whose mean elevation is $1,591 \mathrm{~m}$ a.s.l., is currently expected to be around $400 \mathrm{~mm}$ per year.

Besides systematically underestimating the measured precipitation, the rain-gauge snow undercatch affects also the long-term precipitation trends due to the strong temperature increase occurring over the study period. In order to test the sensitivity of the snow undercatch to temperature, the correction algorithm was applied by both increasing and decreasing the grid-point temperatures by $1^{\circ} \mathrm{C}$ and by comparing the resulting multiplicative coefficients. The temperature is found to have a small but significant influence on the long-term precipitation trend increasing the precipitation values at basin scale of about $1.5-2.0 \%$ per ${ }^{\circ} \mathrm{C}$ of temperature increment. The low effect of temperature on the precipitation trend is also confirmed by deriving the grid-point precipitation anomalies only from the stations that are less affected by rain-gauge snow undercatch (i.e., stations below $500 \mathrm{~m}$ a. s.l. or in the inner valleys of higher elevation areas) and by comparing the annual basin precipitation series with the corresponding series obtained from the full database over the 1921-2016 period, which is the longest period in which high-elevation areas are still represented by a rather good station coverage. The annual differences between the basin precipitation series retrieved from all

\section{(a)}

FI G U RE 10 Temporal evolution of the annual (hydrological year) runoff coefficient: In panel (a) the 1846-2016 series (black solid line) is shown together with a 11-year centred Gaussian filter with 3-year standard deviation (red solid line) and the Theil-Sen linear fit (dashed line); in panel b) the running trend is reported. Trend values are expressed by colours (green to purple positive and yellow to brown negative) while trend significance is represented by the pixel sizes (larger pixels for Mann-Kendall $p$ values <.05)

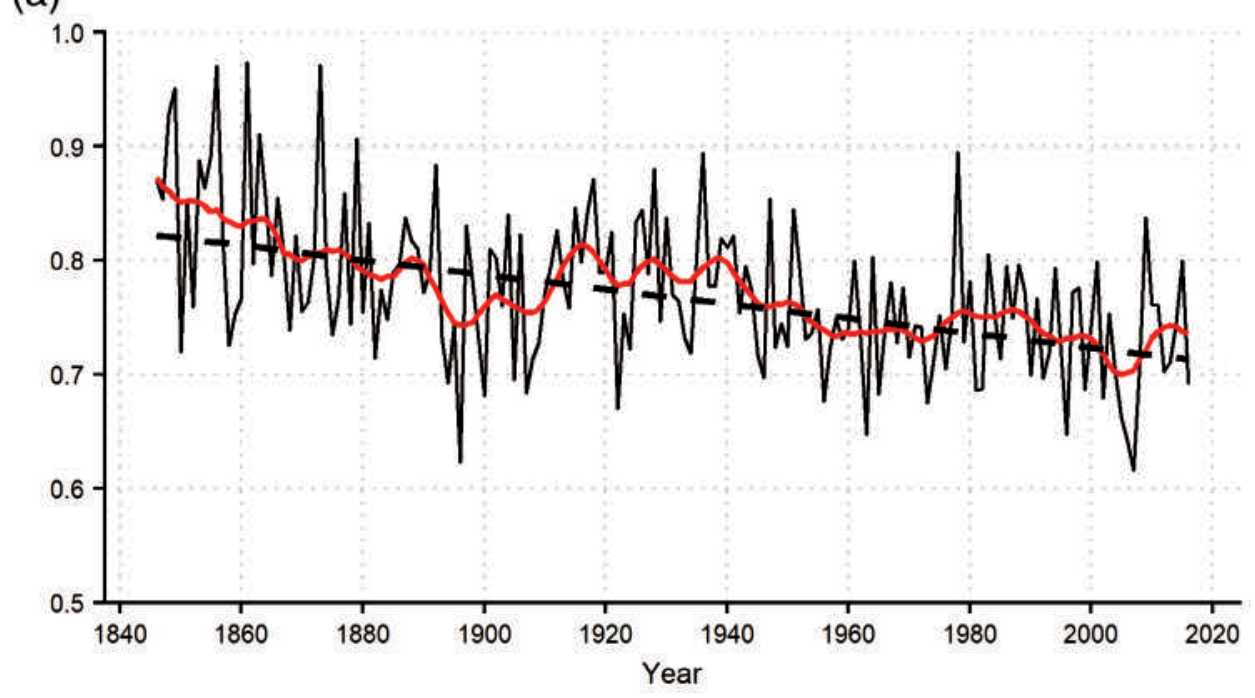

(b)

(\% per decade)

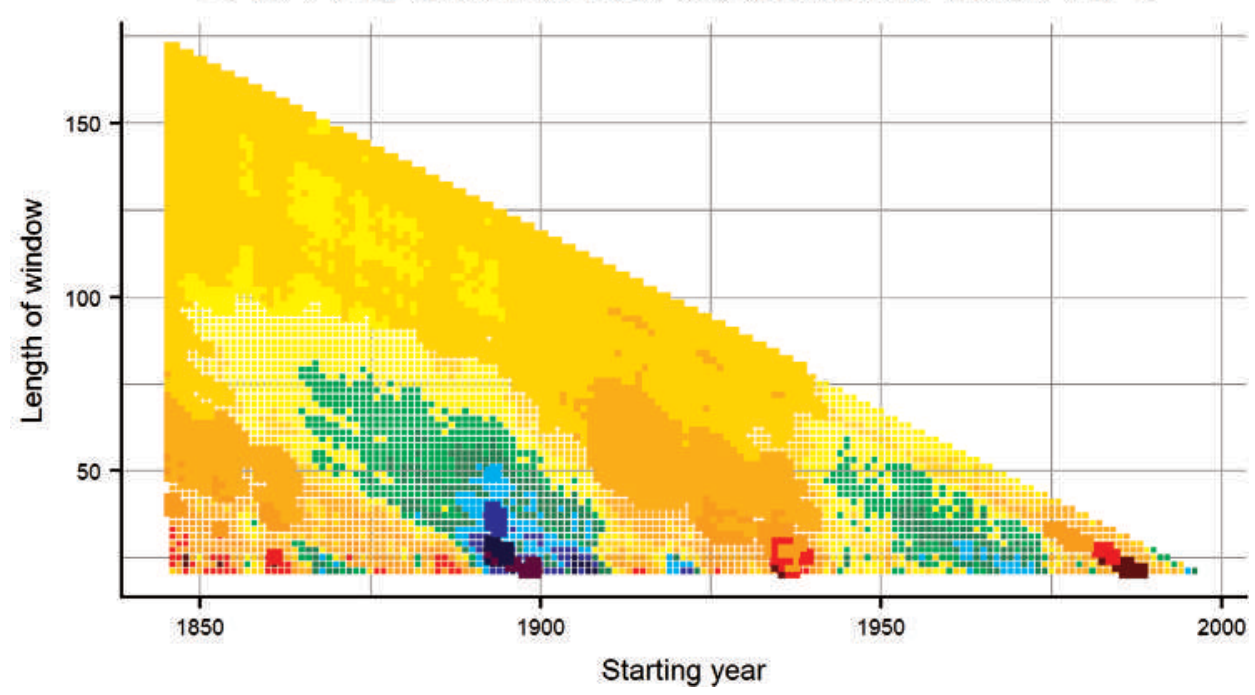


and low-level stations show a positive trend due to a slightly stronger decrease of the precipitation record obtained from the low-level stations. This positive trend is however rather small $\left(17 \mathrm{~mm}\right.$ century $^{-1}$, corresponding to slightly more than $1 \%$ century $^{-1}$ of basin precipitation), even though the temperature trend in this period is rather strong $\left(1.6^{\circ} \mathrm{C}\right.$ century $\left.^{-1}\right)$. Overall, these results suggest that temperature trend induces a positive bias of about $1 \%$ century $^{-1}$ in long-term precipitation trend that is within the error of precipitation trend estimations.

The series of annual runoff coefficients, that is, the ratios between annual runoff and corrected precipitation (Figure 10a), was then subjected to trend analysis. A strongly significant negative trend of $-6.4 \pm 1.0 \%$ century $^{-1}$ was pointed out over the whole period, also confirmed by the running trend graph (Figure 10b), where a significant negative trend is pointed out for almost all windows at least one century long. On shorter time scales significant decreases are also evident for windows starting around 1850 and for time intervals beginning in the 1930s and in the 1980s and spanning 20-30 years.

Moreover, the windows starting at the end of the 19th century and spanning few decades exhibit an increasing tendency which can be explained by the corresponding positive trend of precipitation and resulting increased runoff. The negative trend of the annual runoff coefficient series is due to basin runoff decreasing stronger than basin precipitation. The basin runoff exhibits in fact a rather relevant reduction of $-11.8 \pm 3.2 \%$ century $^{-1}$ (MK $p$ value strongly below 0.01 ) that is clearly stronger than the precipitation decrease, even if the hypothesis of the temperatureinduced positive bias in precipitation record is considered. The TS trends in the 1846-2016 series of annual precipitation, runoff and runoff coefficient based on the hydrological year are summarized in Table 3, in both absolute and relative terms.

The decrease of the runoff coefficient series seems to highlight long-term changes in evapotranspiration probably mainly induced by increasing temperature, as will be discussed more in detail in the companion paper by Ranzi et al. (this issue), focused on the 172-long time series of daily runoff. Another contribution to the variation of the evapotranspiration over the study basin could derive from changes in land use and coverage occurring over the study period, with the expansion of forests enhanced by the gradual decline of human communities and pastures over the mountainous areas (Guidi et al., 2014; Ranzi et al., 2017). It is also worth noting that the recent enhancement of glacier melting could slightly mask the actual long-term decrease in the runoff coefficient which, without the contribution from glacier melting, could be even more negative than observed. This effect has however to be considered together with the positive bias in measured precipitation due to the reduction of the rain-gauge snow undercatch.

\section{4 | CONCLUSIONS}

The 1800-2016 monthly areal precipitation series for the upper part of the Adda river basin (Central Alps) was computed by means of the anomaly method and a quality-checked and homogenized database of monthly station records spanning more than two centuries and covering a wide area centred on the study basin. More specifically, the record was computed from a 30 -arc sec resolution grid of 1800-2016 precipitation series obtained by superimposing the 1961-1990 LWLR climatologies and the corresponding monthly anomalies interpolated by a weighted averaging approach depending on station distance and elevation difference from the target cell.

The temporal evolution of the reconstruction accuracy as well as of the robustness of the areal precipitation estimates in respect to the variability in data coverage was assessed by means of leave-one-out validation and sensitivity tests. The accuracy rapidly increases after the first decades and rather low errors are obtained even for the years of sparse data coverage thanks to the anomaly method which avoids significant underestimations in areal precipitation occurring if the station values were interpolated directly.

Significant negative trends were found for the 1800-2016 annual $\left(-3.8 \pm 1.9 \%\right.$ century $\left.^{-1}\right)$ and autumn $\left(-9.3 \pm 3.8 \%\right.$ century $\left.^{-1}\right)$ areal basin precipitation records, even if the MK $p$ value for the annual signal is above 0.05 if the first decades are excluded from the analysis.

T A B L E 3 TS trend slopes obtained for the study basin annual precipitation, runoff and runoff coefficient over the period 1846-2016

\begin{tabular}{llll} 
& Annual precipitation & Annual runoff & Annual runoff coefficient \\
Absolute & $-46 \pm 37\left(\mathrm{~mm} \cdot\right.$ century $\left.^{-1}\right)$ & $-136 \pm 37\left(\mathrm{~mm} \cdot\right.$ century $\left.^{-1}\right)$ & $-0.064 \pm 0.010\left(\mathrm{century}^{-1}\right)$ \\
Relative & $-3.1 \pm 2.5$ & $-11.8 \pm 3.2$ & $-8.3 \pm 1.3$ \\
& $\left(\%\right.$ century $\left.^{-1}\right)$ & $\left(\%\right.$ century $\left.^{-1}\right)$ & $\left(\%\right.$ century $\left.^{-1}\right)$ \\
\hline
\end{tabular}

Note: The annual totals are based on the hydrological year, that is, from September to August. 
The comparison of the annual basin total precipitation series with the corresponding runoff series over the 1845-2016 period allowed to better investigate both records. For this period, the negative trend of uncorrected and corrected precipitation is $-41 \pm 34$ and $-46 \pm 37 \mathrm{~mm}$ century $^{-1}$, respectively, but none of them is significant at $5 \%$ level.

Firstly, it allowed to discuss the contribution of raingauge snow undercatch to the annual basin precipitation series and to apply a suitable correcting procedure which is needed to explain unrealistic low annual water losses (below $200 \mathrm{~mm}$ ) resulting from the difference between uncorrected precipitation and runoff. The comparison between runoff and corrected precipitation provides current annual evapotranspiration estimates over the basin of about $400 \mathrm{~mm}$, a value consistent with the results reported in literature for the Adda river and rather similar Alpine basins.

Secondly, the precipitation-runoff comparison allowed to highlight a strong decrease in the runoff coefficient series $\left(-6.4 \pm 1.0 \%\right.$ century $\left.^{-1}\right)$ due to a significant reduction of annual runoff of $-11.8 \pm 3.2 \%$ century $^{-1}$. The runoff variation is expected to be mainly determined by the increase in evapotranspiration which is probably driven by both warming and changes in land use and coverage. In addition, a small contribution to runoff could derive from the accelerated melting of basin Alpine glaciers during the recent decades which could slightly reduce the actual runoff losses. The study basin runoff and precipitation records will be released soon in an online repository.

\section{ACKNOWLEDGEMENTS}

Consorzio dell'Adda is acknowledged for having provided runoff data over the period 1946-2016 and water level data before. We also thank all the providers of meteorological data, especially ARPA and CMG for Lombardy, Meteotrentino and the Autonomous Province of Bolzano for Trentino-Alto Adige/Südtirol and MeteoSwiss for Switzerland. Milan University activities have been performed within IPCC MOUPA (Interdisciplinary Project for assessing current and expected Climate Change impacts on MOUntain PAstures), developed within the AGER Project, funded by Fondazione Cariplo.

\section{ORCID}

\section{Alice Crespi (1) https://orcid.org/0000-0003-4186-8474}

\section{REFERENCES}

Auer, I., Böhm, R., Jurkovic, A., Lipa, W., Orlik, A., Potzmann, R., Schöner, W., Ungersböck, M., Matulla, C., Briffa, K., Jones, P., Efthymiadis, D., Brunetti, M., Nanni, T., Maugeri, M., Mercalli, L., Mestre, O., Moisselin, J., Begert, M., Müller-
Westermeier, G., Kveton, V., Bochnicek, O., Stastny, P., Lapin, M., Szalai, S., Szentimrey, T., Cegnar, T., Dolinar, M., Gajic-Capka, M., Zaninovic, K., Majstorovic, Z. and Nieplova, E. (2007) HISTALP - historical instrumental climatological surface time series of the greater alpine region HISTALP. International Journal of Climatology, 27, 17-46. https://doi.org/10.1002/joc.1377.

Beniston, M. (2012) Impacts of climatic change on water and associated economic activities in the Swiss Alps. Journal of Hydrology, 412, 291-296. https://doi.org/10.1016/j.jhydrol.2010.06.046.

Böhm, R., Auer, I., Brunetti, M., Maugeri, M., Nanni, T. and Schöner, W. (2001) Regional temperature variability in the European Alps 1,760-1998 from homogenized instrumental time series. International Journal of Climatology, 21, 1779-1801. https://doi.org/10.1002/joc.689.

Brugnara, Y., Brunetti, M., Maugeri, M., Nanni, T. and Simolo, C. (2012) High-resolution analysis of daily precipitation trends in the Central Alps over the last century. International Journal of Climatology, 32, 1406-1,422. https://doi.org/10.1002/joc.2363.

Brugnara, Y. and Maugeri, M. (2019) Daily precipitation variability in the southern Alps since the late 19th century. International Journal of Climatology, 39, 3492-3504. https://doi.org/10.1002/joc.6034.

Brunetti, M., Lentini, G., Maugeri, M., Nanni, T., Auer, I., Böhm, R. and Schöner, W. (2009) Climate variability and change in the greater alpine region over the last two centuries based on multi-variable analysis. International Journal of Climatology, 29, 2197-2,225. https://doi.org/10.1002/joc.1857.

Brunetti, M., Lentini, G., Maugeri, M., Nanni, T. and Spinoni, J. (2012) Projecting north eastern Italy temperature and precipitation secular records onto a high-resolution grid. Physics and Chemistry of the Earth, Parts $A / B / C, 40-41,9-22$. https://doi. org/10.1016/j.pce.2009.12.005.

Brunetti, M., Maugeri, M., Monti, F. and Nanni, T. (2006b) Temperature and precipitation variability in Italy in the last two centuries from homogenised instrumental time series. International Journal of Climatology, 26, 345-381. https://doi.org/10.1002/joc.1251.

Brunetti, M., Maugeri, M., Nanni, T., Auer, I., Böhm, R. and Schöner, W. (2006a) Precipitation variability and changes in the greater alpine region over the 1800-2003 period. Journal of Geophysical Research, 111(111), D11107. https://doi.org/10.1029/2005JD006674.

Brunetti, M., Maugeri, M., Nanni, T., Simolo, C. and Spinoni, J. (2014) High-resolution temperature climatology for Italy: interpolation method intercomparison. International Journal of Climatology, 34, 1278-1,296. https://doi.org/10.1002/joc.3764.

Casty, C., Wanner, H., Luterbacher, J., Esper, J. and Böhm, R. (2005) Temperature and precipitation variability in the European Alps since 1,500. International Journal of Climatology, 25, 1855-1880. https://doi.org/10.1002/joc.1216.

Consorzio dell'Adda (2003). Gli effetti della regolazione sulle portate dell'Adda e sulle piene del lago di Como. Vol. 12. Milano.

Craddock, J. (1979) Methods of comparing annual rainfall records for climatic purposes. Weather, 34, 332-346. https://doi.org/10. 1002/j.1477-8696.1979.tb03465.x.

Crespi, A., Brunetti, M., Lentini, G. and Maugeri, M. (2018) 1961-1990 high-resolution monthly precipitation climatologies for Italy. International Journal of Climatology, 38, 878-895. https://doi.org/10.1002/joc.5217.

Daly, C., Gibson, W.P., Taylor, G.H., Johnson, G.L. and Pasteris, P. (2002) A knowledge-based approach to the statistical mapping 
of climate. Climate Research, 22, 99-113. https://doi.org/10 3354/cr022099.

Durand, Y., Laternser, M., Giraud, G., Etchevers, P., Lesaffre, B. and Mérindol, L. (2009) Reanalysis of $44 \mathrm{Yr}$ of climate in the French Alps (1958-2002): methodology, model validation, climatology, and trends for air temperature and precipitation. Journal of Applied Meteorology and Climatology, 48, 429-449. https://doi.org/10.1175/2008JAMC1808.1.

Eccel, E., Cau, P. and Ranzi, R. (2012) Data reconstruction and homogenization for reducing uncertainties in high-resolution climate analysis in alpine regions. Theoretical and Applied Climatology, 110, 345-358. https://doi.org/10.1007/s00704-012-0624-z.

EEA (European Environment Agency) (2009) Regional climate change and adaptation. The Alps facing the challenge of changing water resources. EEA Technical Report, 143 pp. https://doi. $\operatorname{org} / 10.2800 / 12552$

Efthymiadis, D., Jones, P.D., Briffa, K.R., Auer, I., Böhm, R., Schöner, W., Frei, C. and Schmidli, J. (2006) Construction of a 10-min-gridded precipitation data set for the greater alpine region for 1800-2003. Journal of Geophysical Research, 111, D01105. https://doi.org/10.1029/2005JD006120.

Fatichi, S., Rimkus, S., Burlando, P. and Bordoy, R. (2014) Does internal climate variability overwhelm climate change signals in streamflow? The upper Po and Rhone basin case studies. Science of the Total Environment, 493, 1171-1,182. https://doi.org/ 10.1016/j.scitotenv.2013.12.014

Foresti, L., Sideris, I., Panziera, L., Nerini, D. and Germann, U. (2018) A 10-year radar-based analysis of orographic precipitation growth and decay patterns over the Swiss alpine region. Quarterly Journal of the Royal Meteorological Society, 144, 2277-2,301. https://doi.org/10.1002/qj.3364.

Frei, C. and Schär, C. (1998) A precipitation climatology of the Alps from high-resolution rain-gauge observations. International Journal of Climatology, 18, 873-900. https://doi.org/10.1002/( SICI)1097-0088(19980630)18:8<873::AID-JOC255>3.0.CO;2-9.

Golzio, A., Crespi, A., Bollati, I.M., Senese, A., Diolaiuti, G.A., Pelfini, M. and Maugeri, M. (2018) High-resolution monthly precipitation fields (1913-2015) over a complex mountain area Centred on the Forni Valley (central Italian Alps). Advances in Meteorology, 2018, 9123814, 17. https://doi.org/10.1155/2018/ 9123814.

Grossi, G., Lendvai, A., Peretti, G. and Ranzi, R. (2017) Snow precipitation measured by gauges: systematic error estimation and data series correction in the central Italian Alps. Water, 9, 461. https://doi.org/10.3390/w9070461.

Guidi, C., Vesterdal, L., Gianelle, D. and Rodeghiero, M. (2014) Changes in soil organic carbon and nitrogen following forest expansion on grassland in the southern Alps. Forest Ecology and Management, 328, 103-116. https://doi.org/10.1016/j. foreco.2014.05.025.

Gurtz, J., Baltensweiler, A. and Lang, H. (1999) Spatially distributed hydrotope-based modelling of evapotranspiration and runoff in mountainous basins. Hydrological Processes, 13, 2751-2,768. https://doi.org/10.1002/(SICI)1099-1085(19991215)13:17<2751:: AID-HYP897>3.0.CO;2-O.

Gyalistras, D. (2003) Development and validation of a highresolution monthly gridded temperature and precipitation data set for Switzerland (1951-2000). Climate Research, 25, 55-83. https://doi.org/10.3354/cr025055.
Haylock, M.R., Hofstra, N., Klein Tank, A.M.G., Klok, E.J., Jones, P.D. and New, M. (2008) A European daily highresolution gridded data set of surface temperature and precipitation for 1950-2006. Journal of Geophysical Research, 113, D20119. https://doi.org/10.1029/2008JD010201.

Isotta, F.A., Frei, C., Weilguni, V., Perčec Tadić, M., Lassègues, P., Rudolf, B., Pavan, V., Cacciamani, C., Antolini, G., Ratto, S.M., Munari, M., Micheletti, S., Bonati, V., Lussana, C., Ronchi, C., Panettieri, E., Marigo, G. and Vertačnik, G. (2014) The climate of daily precipitation in the Alps: development and analysis of a high-resolution grid dataset from pan-alpine rain-gauge data. International Journal of Climatology, 34, 1657-1675. https://doi. org/10.1002/joc.3794.

Kendall, M.G. (1975) Rank Correlation Methods. London: Griffin.

Masson, D. and Frei, C. (2016) Long-term variations and trends of mesoscale precipitation in the Alps: recalculation and update for 1901-2008. International Journal of Climatology, 36, 492-500. https://doi.org/10.1002/joc.4343.

Mitchell, T.D. and Jones, P.D. (2005) An improved method of constructing a database of monthly climate observations and associated high-resolution grids. International Journal of Climatology, 25, 693-712. https://doi.org/10.1002/joc.1181.

New, M., Todd, M., Hulme, M. and Jones, P. (2001) Precipitation measurements and trends in the twentieth century. International Journal of Climatology, 21, 1899-1922. https://doi.org/10. 1002/joc. 680 .

Pavan, V., Antolini, G., Barbiero, R., Berni, N., Brunier, F., Cacciamani, C., Cagnati, A., Cazzuli, O., Cicogna, A., De Luigi, C., Di Carlo, E., Francioni, M., Maraldo, L., Marigo, G., Micheletti, S., Onorato, L., Panettieri, E., Pellegrini, U., Pelosini, R., Piccinini, D., Ratto, S., Ronchi, C., Rusca, L., Sofia, S., Stelluti, M., Tomozeiu, R. and Torrigiani Malaspina, T. (2019) High resolution climate precipitation analysis for north-Central Italy, 1961-2015. Climate Dynamics, 52, 3435-3453. https://doi.org/10.1007/s00382-018-4337-6 .

Ranzi, R. and Bacchi, B. (1998) Il bilancio idrologico nelle aree montane per la stima delle disponibilita idriche: alcuni problemi aperti. XXVI Convegno di Idraulica e Costruzioni Idrauliche, Catania, 3, 347-358.

Ranzi, R., Caronna, P. and Tomirotti, M. (2017) Impact of climatic and land use changes on riverflows in the Southern Alps. In: Kolokytha, E. , Oishi, S. and Teegavarapu, R.S.V. (Eds.) Sustainable Water Resources Planning and Management Under Climate Change. Singapore: Springer Science+Business Media, pp. 61-83. https://doi.org/10.1007/978-981-10-2051-3.

Ranzi, R., Grossi, G. and Bacchi, B. (1999) Ten years of monitoring areal snowpack in the southern Alps using NOAA-AVHRR imagery, ground measurements and hydrological data. Hydrological Processes, 13, 2079-2095. https://doi.org/10.1002/(SICI) 1099-1085(199909)13:12/13<2079::AID-HYP875>3.0.CO;2-U.

Ranzi, R., Michailidi, E.M., Tomirotti, M., Crespi , A., Brunetti, M. and Maugeri, M. (2020) A multi-century meteo-hydrological climatology for the Adda river basin (Central Alps). Part II: daily runoff (1845-2016) at different scales. International journal of climatology. https://doi.org/10.1002/joc.6614. [Epub ahead of print].

Richter, D. (1995) Ergebnisse methodischer Untersuchungen zur Korrektur des systematischen Messfehlers des Hellmannniederschlagsmessers, Berichte des Deutschen Wetterdienstes, Vol. 194. 
Schaefli, B., Hingray, B. and Musy, A. (2007) Climate change and hydropower production in the Swiss Alps: quantification of potential impacts and related modelling uncertainties. Hydrology and Earth System Sciences, 11, 1191-1,205. https://doi.org/ 10.5194/hess-11-1191-2007.

Scherrer, S.C., Fischer, E.M., Posselt, R., Liniger, M.A., CrociMaspoli, M. and Knutti, R. (2016) Emerging trends in heavy precipitation and hot temperature extremes in Switzerland. Journal of Geophysical Research Atmosphere, 121, 2626-2,637. https://doi.org/10.1002/2015JD024634.

Schmidli, J., Schmutz, C., Frei, C., Wanner, H. and Schär, C. (2002) Mesoscale precipitation variability in the region of the European Alps during the 20th century. International Journal of Climatology, 22, 1049-1,074. https://doi.org/10.1002/joc.769.

Servizio Idrografico (1920) Osservazioni pluviometriche raccolte a tutto l'anno 1915. Vol. II: Bacino Imbrifero del Po. Fascicolo I, Roma: Ministero dei Lavori Pubblici - Consiglio Superiore delle Acque.

Servizio Idrografico (1925) Osservazioni pluviometriche raccolte nel quinquennio 1916-1920. Pubblicazione numero 1 del Servizio Idrografico. Volume V: Bacino del Po, Roma.

Servizio Idrografico (1959) Precipitazioni medie mensili ed annue e numero dei giorni piovosi per il trentennio 1921-1950. Pubblicazione numero 24 del Servizio Idrografico. Fascicolo XII b, Roma.
Sevruk, B. (1985) Correction of precipitation measurements. Proceedings of Workshop on the Correction of Precipitation Measurements, Zurich, Switzerland, WMO/IAHS/ETH, 13-23.

Sevruk, B., Ondrás, M. and Chvíla, B. (2009) The WMO precipitation measurement intercomparisons. Atmospheric Research, 92, 376-380. https://doi.org/10.1016/j.atmosres.2009.01.016.

Theil, H. (1950) A rank-invariant method of linear and polynomial regression analysis. I. Proceedings of the Koninklijke Nederlandse Akademie van Wetenschappen, A53, 386-392.

Viviroli, D., Dürr, H.H., Messerli, B., Meybeck, M. and Weingartner, R. (2007) Mountains of the world, water towers for humanity: typology, mapping, and global significance. Water Resources Research, 43, W07447. https://doi.org/10.1029/ 2006WR005653.

How to cite this article: Crespi A, Brunetti M, Ranzi R, Tomirotti M, Maugeri M. A multi-century meteo-hydrological analysis for the Adda river basin (Central Alps). Part I: Gridded monthly precipitation (1800-2016) records. Int J Climatol. 2020;1-19. https://doi.org/10.1002/joc.6614 